\title{
Editorial
}

\section{Globalization, public sector reform, and the role of ports in international supply chains}

\author{
Hercules Haralambides
}

Econometric Institute, Erasmus University Rotterdam, Burg. Oudlaan 50, 3062 PA Rotterdam, The Netherlands.

E-mail: haralambides@ese.eur.nl

Maritime Economics \& Logistics (2017) 19, 1-51. doi:10.1057/s41278-017-0068-6

\section{Introduction}

The first rough brushstrokes of this editorial were put 20 years ago, mostly in the later part of this paper concerning the subject of port reform. At the time, I was working for ILO, on the labor aspects of structural adjustment programs, as well as for the European Commission (Commissioner Kinnock), on matters of European port policy. Since then, the text has expanded substantially to include globalization, containerization, the 'mega-ship' controversy, port competition, transshipment, financing of ports, port labor, and general port management issues. Most of the latter issues derive partly from my recent experiences as president of the port of Brindisi: a provincial town of southern Italy (Apulian Region) which taught me the problems of economic dualism, underdevelopment, and north-south divides in the best possible hands-on way. Readers are strongly advised not to skip my frequent footnotes, which I hope many will find most entertaining. Many of my countless revisions, improvements, updates, and additions have appeared earlier in various forms, including posts on my blog, and some are also included in these footnotes. Finally, it is not without some satisfaction to see, through this review, that almost everything I was predicting all these years on the evolution of ports towards entrepreneurial entities, and the diseconomies of scale posed by mega-ships on ports, shippers, and the supply chain, have come true in 2017. 


\section{Global forces driving port reform}

During a meeting of the UNCTAD Intergovernmental Group of Experts on Ports, port commercialization, corporatization, and privatization were subjects that evoked not only exceptional interest and enthusiasm, but also concern among delegates. ${ }^{1}$ Such discussions would have been unimaginable 20 years ago, when most governments were considering their port sector as one requiring massive public investment for port development; of strategic interest to the nation; or a service industry, crucial to the common interest.

However, in the last 20 years, there has been a worldwide trend of structural reform of the public sector. In some developed as well as developing countries, this has taken the form of commercialization or privatization of public enterprises. In the former USSR, and in the socialist countries of Eastern Europe and Asia, the overarching objective of structural reforms was to transform centrally planned economies into market economy systems. Globalization, free trade, and the ensued fierce national and international competition have been the major motors of such changes.

Globalization could be described as the increase in cross-border interdependences and, more profoundly, integration, as a result of the greater mobility of factors of production and of goods and services (Campbell 1994; Milanovic 2012). This remarkable mobility can be attributed to three major factors:

- Trade liberalization, the abolition of national frontiers, advances in transportation, information technology, mass media, advertising, secularism have all led to a remarkable convergence of world cultures and consumption patterns, resulting in larger international markets and intensified competition. Due to economies of scale in ocean transportation, distance no longer matters and the world is shrinking inside the frame of our computer screen.

- Most governments are rather convinced that economic integration, promoted by the globalization of capital markets and the virtual abolition of currency controls, leads to more efficient resource allocation and hence it stimulates growth and economic development.

- The significant advances in transport and communications technologies have increased the speed and efficiency of transport and lowered the costs of communication. These developments have lowered the barriers of time and distance and give the impression of a "shrinking world" (Dicken 1992; Oxford Economics 2011).

\footnotetext{
${ }^{1}$ I often use the three terms interchangeably, under the overall characterization 'port reform.' Here the latter term is meant as the gradual retrenchment of the public sector from economic activity and the introduction of commercial principles in port management.
} 
In this way, globalization and trade liberalization, helped by the significant developments in transport, logistics, and communication technologies, have drastically weakened the link between manufacturing and the location of the factors of production; they have expanded markets for goods and services; and have led to a most noticeable shift in manufacturing activities towards countries with a comparative advantage. As an example, as early as the 1980s, more than half of the employees of Sweden's 30 largest manufacturing companies (ranked by employment) were working in foreign subsidiaries. At the same time, the internet has reduced long distance communication costs to almost nil. This, together with the liberalization of communications networks, and their simultaneous use by telephone, television, and computer companies, has undoubtedly brought about changes in societal structures as radical and unpredictable now as the Manhattan, Hong Kong, Shanghai, and Dubai skylines would have been to Thomas Edison when the discovery of electricity made possible the use of the elevator.

The need for reform in developing countries' economies has been as much the result of their own precarious economic and social situation as of the fact thatwithout having been adequately prepared-developing countries have been exposed to the relentless forces of globalization and intensified international competition. This exposure has been taking place simultaneously with the opening-up of their internal markets, so that they could take advantage of the recent developments in the liberalization of international trade, particularly of the many favorable "developing country provisions" of the GATT/WTO.

Twenty years later (2017), developing countries have been proven right, with China being now the champion of both free trade and environmental awareness. Most developing countries are now well aware of the tremendous potential benefits from the opening-up of their internal markets and the liberalization of their external trade. These benefits are, of course, the result of their comparative advantage, due to their still low-basis growth in industrialization (and thus their potential of achieving significant economies of scale) and their inexpensive labor force.

On the contrary, the western world has been losing out in this zero sum game, as it has proven to be after all. The West's initial enthusiasm with globalization and trade liberalization was based on a false premise, i.e., its saturated economies and increasing returns to scale industries could only survive if and only if the West could expand the international market for its exports. Unfortunately, this did not happen. Instead of producing 'here' and exporting 'there,' Foreign Direct Investment (FDI) started to flow 'there,' producing 'there' and, often, re-importing back 'here.' Profits of European multinational companies have not been repatriated in a way that would allow us to sustain our welfare systems and way of life, developed over decades with the 
taxes of our fathers and forefathers. These systems are now being unraveled in the pursuit of the Holy Grail of cost competitiveness, and as a result of a mentality of 'cheap consumerism' which, if it does not change, it will be signing the economic death certificate of, at least, Europe.

At the time of writing (2017), the landscape appears to be changing again and the outcome is still unpredictable to most analysts. The global economic meltdown of 2009 , coupled with massive emigration waves heading mostly towards Europe, and last but not least the election of Donald Trump to the presidency of the United States have alarmingly raised nationalist, isolationist, and protectionist voices throughout Europe and North America. As evidence of this one could not fail to observe that the annual growth rate of international trade, in the post-crisis period, is half of what it used to be before 2009. Still, and I would be amiss not to say it at this point, we continue building ships and ports as if nothing has happened.

Apart from the rather obvious direct benefits of an export-led growth strategy, trade liberalization and the opening of internal markets have also helped developing countries to acquire all the necessary technology, knowhow, and foreign expertise that, together with the subsequent increased levels of Foreign Direct Investment (FDI), allowed them to accelerate the process of their economic development.

In many cases, a dynamic growth strategy, based on liberalization and economic reform, is providing solutions to the severe problems of overpopulation which plague the economic and natural environment of many developing countries. Policies to promote growth and personal freedom are considered by many countries as the only safe way to curb the growth of population. As incomes and standards of living rise, fertility rates in developing countries are bound to drop, as they have already done in the industrialized world.

An export-led growth strategy, however, necessitates the adjustment of the economic, commercial, and, many times, social characteristics of a nation to the business ethics and practices employed in the game of international competition; and this is not always easy. In the rapidly changing world of technological innovation and of sophisticated demand requirements (logistics), the transition of many economies to market-oriented business practices, developed primarily in the western world, cannot be always smooth. Furthermore, the time required for the gradual assimilation of such practices into economic and social conscience is not always available. Finally, the necessary processes of economic and social reform will be many times resisted by various groups who, sometimes quite justifiably, aim at safeguarding a country's environment, ethics, traditions, cultures, and religious values.

It has often been argued that high port and transport costs (see below) hurt developing countries' exports which are already little diversified and overdependent on the very volatile international commodity prices. For this reason, 
developing countries have often refuted the principle of comparative advantage as one that leads to a worsening in their terms of trade, creates balance of payments bottlenecks, and thus hinders their efforts to grow through diversification. Nowadays, there is another equally important factor that compounds this problem. This factor, or rather series of factors, consists of the complex developments in multimodal integrated transport, logistics networks, and electronic data interchange.

Preferential trading relationships between North and South, inherited from colonial business practices, assume a far less important role today than they did in the past. Today, independent trading houses and multimodal transport operators have the possibility, at a keystroke, to scan the world commodity and product markets and select routes, methods of shipment and carriers in such an integrated manner that ensures quality, expediency, and reliability while at the same time optimizes generalized costs as well as cost-time trade-offs.

This situation makes the demand for developing countries' exports much more vulnerable now than it used to be in the past. This vulnerability is not only a function of export prices but also a function of developing countries' (in)ability to comply with modern business and trading practices which are not inflicted upon them in a Machiavellian way, as some could argue, but are rather consumer and technology driven and oriented.

In such an environment, any factor, however small, that can blunt a country's export competitiveness is bound to have much graver ramifications today than in the past. Governments are increasingly realizing that the poor performance of their public ports, and their high costs, are hampering trade and disadvantage the national economy. This is especially true for most countries in the early stages of economic development. The proportion of port costs in the final price of traded goods varies significantly from $0.2 \%$, for cargo of high value per ton, to over $20 \%$ for low-value cargoes. The trade structure of most developing countries shows that their export products are mainly of the latter type (low value-added). Although more and more developing countries enter the world market with manufactured goods, they have in fact been providing low-end products, competing through price rather than quality. Consequently, port performance plays a bigger role for them than for developed market economies.

Differences in international transport costs (including port costs) between developed and developing countries, but also among developing countries themselves, are substantial (Fig. 1). Developing countries pay at least $50 \%$ more for the transport of their imports than developed countries; but even within developing countries themselves, differences are pronounced: Africa pays twice as much as Asia and Latin America for its imports.

The high elasticity of the international demand for developing countries' exports and the low short-run elasticity of supply of most agricultural and mining 


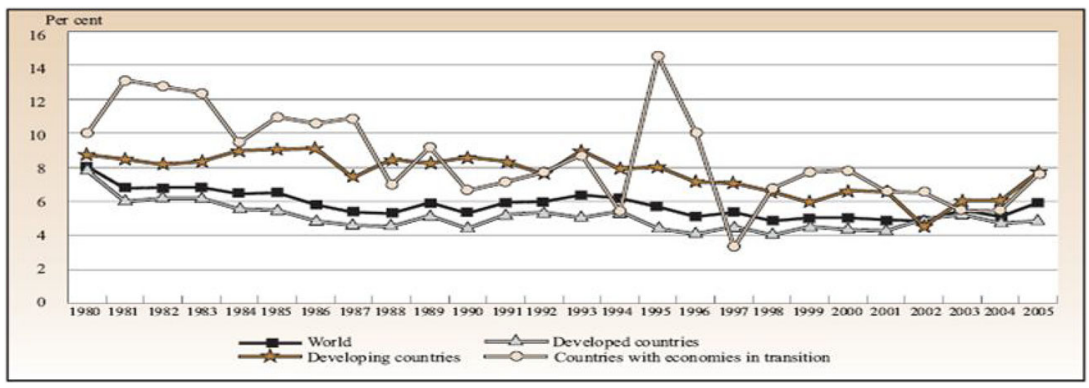

Fig. 1: Freight costs as (\%) of the value of imports 1980-2005 Source UNCTAD

goods they produce often leave developing countries with very slim profit margins that can be easily swallowed by high transport and port costs. In view of the high elasticity of demand and low elasticity of supply, the incidence of transport costs is unfavorable to developing countries, and any transport cost increases will have to be absorbed in the FOB prices exporters are enjoying (Fig. 2).

The exports of soybeans can serve as a good example. In 1991, the international FOB price for soybeans was $\$ 230$ per ton. However, loading the cargo on board a ship cost $\$ 65$ per ton in the port of a South American country, while it cost only $\$ 20$ per ton in a North American port. Although the production cost of soybeans per ton was $\$ 165$ in South America, i.e., \$30 cheaper than in North America, the result was that by selling soybeans at the international market, the South American producers made no profit at all, while their North

\section{Incidence of Transport Costs with Inelastic Supply (the case of agricultural products from developing countries)}

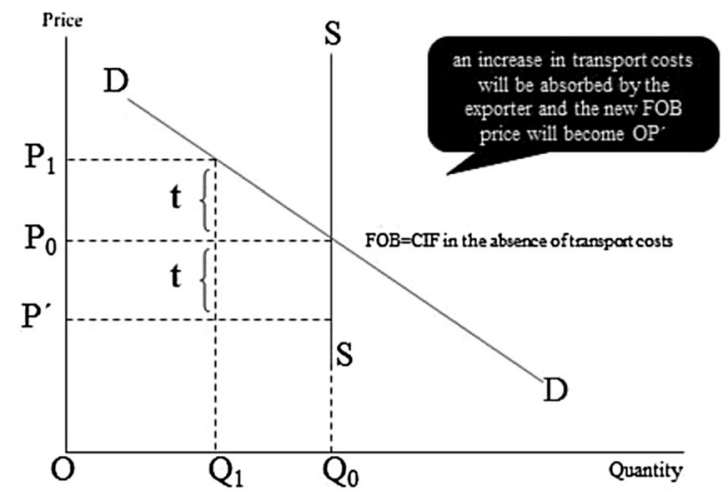

Fig. 2: Incidence of transport costs 
American rivals were realizing a \$15 per ton profit. Poor port services were thus not only taking profits away from the national exporters, but in fact they were squeezing the country out of the world market.

\section{Liner shipping and the container revolution}

It is sometimes said that unitization, particularly containerization, has revolutionized the transport and port industries. Such an emphatic characterization could be quite acceptable if one considers the enormous impact this originally purely technical solution in cargo-handling methods had on the design and sizes of general cargo ships; the lay-out, equipment, development, operations, and employment in ports; on inland transport requirements; land use; human skills; and shippers' perceptions regarding the functioning of the overall supply chain.

Containerization has had a number of significant advantages over the conventional, labor-intensive methods of handling general cargo. Apart from the remarkable improvements in port safety and the limitation of pilferage, damages and cargo claims, the system's major breakthroughs-particularly in the U.S. where it was first introduced-were in cutting down on expensive and often abusively unionized labor, as well as reducing ship turnaround times.

Due to costly, grossly ineffective, and time-consuming cargo-handling methods prior to the advent of containerization, general cargo ships were known to spend most of their operational time in ports, waiting, loading, or unloading. In many instances, and whenever possible, shippers were thus avoiding ports, shifting cargo to road and rail transport instead, for long distance carriage.

Expediency in cargo-handling was necessitated by the very nature of general cargo goods whose increasing sophistication and value required fast transit times from origin to destination in order to increase shippers' turnover and minimize high pipeline- and inventory costs. The latter costs were thus brought down significantly by the use of logistical concepts and methods, as well as by the increased reliability and accuracy of liner shipping operations that allowed manufacturing industries to adopt flexible Just-in-Time and Make-toOrder production technologies. Among a host of other benefits, such technologies enabled companies to cope with the vagaries and unpredictability of the seasonal business and trade cycles and plan business development with more certainty. Many shippers in industrialized countries were thus more than happy to bear the increased initial costs involved in the introduction of the new transport system (containerization), given that these costs were only a fraction of the benefits enjoyed by faster transit times and the higher predictability of cargo movements. 
The dramatic improvements in cargo-handling operations, brought about by the introduction of containerization, have enabled general cargo ships to spend hours or days now in ports, rather than weeks or months that was customary before. The reduction of port time and the corresponding increase in time at sea have eventually led to the substitution of the previous multipurpose general cargo ships by specialized high-speed container vessels of substantially (and ever increasing) larger dimensions that can take advantage of the economies of scale afforded by the shorter port turnaround times. Port efficiency and productivity have thus been the main drivers behind the increase in containership sizes, particularly since 1988 when American President Lines introduced the post-Panamax vessels (Fig. 3). Up to that year, the maximum size of containerships (and of course of other types of vessels) was determined by the width of the Miraflores locks of the Panama canal and it had remained constant, at around 4400 TEU, for almost a decade.

Liner shipping has thus become an extremely capital-intensive industry. Many modern deep-sea cellular containerships have capacity to carry more than 19,000 TEUs, developing speeds of about 25 knots. Depending on market conditions, the construction cost of such a ship may well exceed 100 million USD. Already in 1972, a 3000 TEU vessel appeared in the big consortium Europe-Far East (Couper 1986) and during the same year the world's container

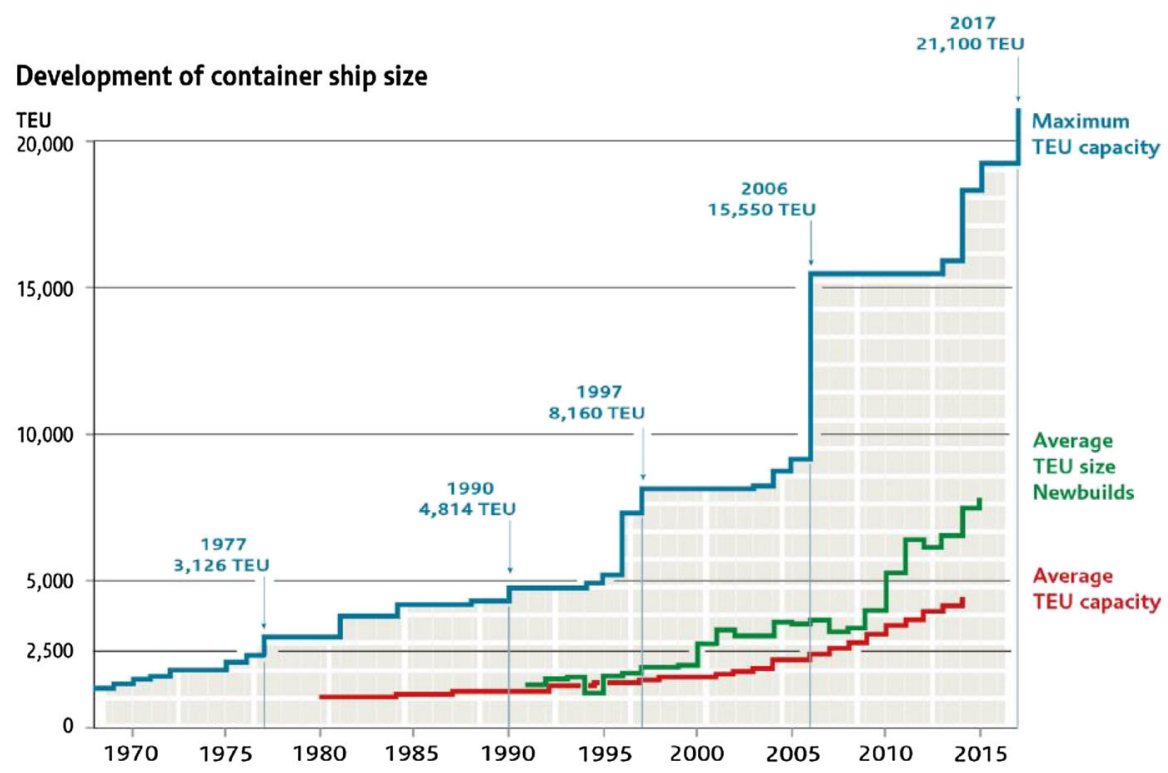

Fig. 3: Developments in the maximum size of containerships Source OECD/ITF based on data from Clarkson Research Services 
port league enlisted 82 main ports in the starting phases of the race towards container traffic growth (Beplat 1989). In less than 30 years since the introduction of the first post-panamax containership, ship sizes have more than quadrupled while, as a result of competition in shipbuilding and the emergence of new shipbuilding countries (Korea and China), the construction cost of such as ship is not much different than the construction cost of a Panamax ship (4800 TEU) 20 years earlier (1996).

However, economically justified investments in containerization might have been in the industrialized countries facing the north Atlantic and Pacific oceans (where the bulk of general cargo traffic is concentrated), some developing countries have reacted to the necessity of this type of investments with varying degrees of skepticism. Their allegedly legitimate worries concerned the suitability of capital-intensive techniques in countries with abundant and inexpensive labor; their lack of financial resources together with other pressing investment priorities in the country; and also the fact that the vast majority of their exports (primarily raw materials and agricultural produce) were not "containerisable."

Furthermore, the capital-intensive nature of liner shipping and the consequent "operational arrangements" within this industry, in the form of consortia and similar types of co-operation, frustrated many developing countries' plans to get actively involved in liner shipping, despite their cargosharing entitlements secured mainly through the provisions of the UNCTAD Code of Conduct of Liner Conferences. ${ }^{2}$ For many developing countries, the result of this situation was that they were often seen to be played off against each other by major liner operators who had been convincingly arguing that if adequate port investments in container-handling facilities and equipment were not timely made, ports would be by-passed by major lines and thus become backwaters. In many cases, this argument was driven home very successfully for a number of reasons:

- No developing country would fail to see the importance of efficient national ports as facilitators to trade and as crucial elements in their process of economic development.

\footnotetext{
2 The United Nations Conference of Plenipotentiaries on a Code of Conduct for Liner Conferences, better known as the UNCTAD Code, came into force in October 1983. The Code, result of political pressure on the side of developing countries, was nothing more than a protectionist cargo-sharing arrangement, on the basis of its infamous 40-40-20 formula, whereby trade was reserved for the ships of the two trading nations, leaving only a $20 \%$ open to the ships of third countries. The United States never ratified the Convention, whereas the European Union did so reluctantly and conditionally on the basis of the Brussels Package. In sort, the latter ensured that the restrictions of the Code would not apply among EU member states, as well as between them and other OECD countries.
} 
- The increase in sizes, sophistication, and capital intensity of modern containerships in deep-sea liner trades has limited the number of ports of call to only a select few transshipment ports or load centers. These very important ports have become the foci of international shipping, and goods are moved by land (road and rail) and water (barge) from inland centers and feeder ports to these global hubs (Slack and Starr 1994).

- Many developing countries have thus taken up the challenge to develop their ports, hopefully into load centers, under keen competition with other regional ports having similar aspirations. These decisions were taken not only because of fear that ports would be by-passed if they did not do so, but also on the grounds of some other more pro-active considerations. It was thus thought that the development of container-handling facilities in excess of national traffic demand requirements might have the positive spin-off effects of an unbalanced growth approach to development. According to this, basic infrastructural facilities (such as ports) are built up far ahead of existing demand, on the part of the industry, agriculture, and commerce, in the hope that the latter activities will expand by the wake of the former (Rosenstein-Rodan 1943).

- Apart from considerations of trade facilitation, a number of countries, particularly in Asia, saw port containerization as an export industry in its own right. It was thus considered that, additionally to their direct financial benefits, the export of transshipment services to neighboring countries would enable ports to grow and achieve significant economies of scale (not otherwise warranted by the country's limited domestic traffic) that would finally benefit the country's external trade itself.

- Finally, transshipment traffic would allow the development of feeder service networks for the regional distribution of containers and this would enable the country in question to get profitably involved in shipping (at least the shortsea type of) and value-added distribution activities that would otherwise be lost to competing regional ports. Feeder services and inland transport and distribution possibilities were major considerations by countries seriously contemplating investment in containerization. This was so, given that most countries were realizing that if such possibilities did not exist, the likelihood of them being selected as major "hubs" would be rather thin, no matter how efficiently they might like to develop and run their ports.

\section{Diseconomies of scale at ports and the "mega-ship" controversy}

In spite of its tremendous advantages, however, containerization has gradually led to the commoditization of the ocean liner service and thus to higher competition among carriers. In an effort to differentiate their service, as well as 
better control the supply chain, in the 1990s carriers started to invest in the other components of the supply chain, such as container terminals, distribution centers, road, rail, and air transport, and in a miscellany of other logistics services, such as bar-coding, assembly, documentation. Investment in logistics services and related infrastructure, rather than in ships, - which, incidentally, could be chartered-in from private equity investors (e.g., KG funds in Germany)-allowed carriers to become more asset light, thus more agile in coping with the vagaries of the business cycle. In addition to service differentiation, vertical integration also served in increasing both the complexity of operations and the sunk costs of aspiring new competitors (carriers), particularly if shippers are convinced, through effective marketing, that an integrated door-to-door service is the only way to better serve their requirements.

This situation has started to change. Carriers appear to be returning back to core business, shedding the idea of vertical integration in favor of better horizontal integration (alliances) and dominance in the sector (shipping) where they have the comparative advantage. Partly, this return to roots has been the result of the weakening or banning of liner conferences, and the low freight rates and service unreliability that ensued as a result. Presently, you can bring a container from Hong Kong to Rotterdam with \$300; far below break-even point. Laid up container tonnage is around $5 \%$ of the total fleet (over one million slots) and, interestingly, it is often the largest and newest ships, such as MSC Oscar, which are laid up. To no avail, consignees are desperately looking for someone to talk to on the phone. In complex ports like Los Angeles, the terminal of arrival is often unknown until the last minute. At the other end, in Asia, to be filled, a mega-ship would call at far more ports than what its size would warrant; something creating a stowage nightmare at the receiving ports. In short, you have a ghastly mess, ${ }^{3}$ brought about by the shippers themselves in their obsession to do away with the liner conference system.

If you ask an ocean carrier how big a port should be, he would immediately tell you "as big as possible." Apparently, he would not want to wait even for a minute if he could help it, and we have well established that, at a port capacity utilization of around $75 \%$, congestion starts to set in. If instead you ask the same question to a port manager, particularly one responsible for the returns on his money, the answer would be "as small as possible." Obviously, he would love having ships queuing up outside his port, like the good old times, if he could help it. As usual, both need to put some water in their wine and compromise (Fig. 4): the ship cannot wait, nor however can the port continue spending taxpayer

\footnotetext{
${ }^{3}$ Lyrics from "The life I Lead" (Mary Poppins) [...] A British bank is run with precision. A British home requires nothing less. Tradition, discipline, and rules must be the tools; without them: disorder, catastrophe, anarchy, in short you have a ghastly mess...
} 


\section{Optimum Containership Size and Diseconomies at Ports (the need for joint optimization)}

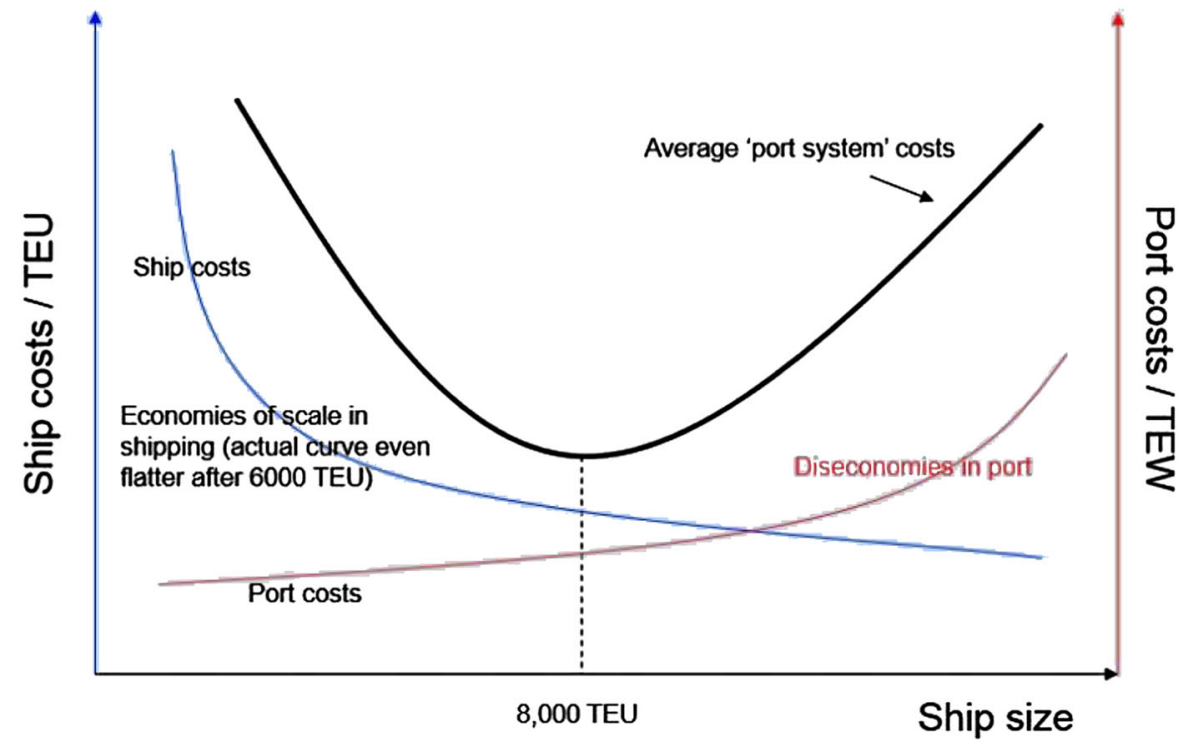

Fig. 4: Optimum containership size and diseconomies at ports

money so that the ship does not do so. This is particularly so in increasingly commercial activities, such as those of transshipment container terminals, whose impacts are not localized in the economies which have borne the brunt of the investment, but are rather dissipated throughout the supply chain, from the country of origin to the country of final destination of the transported goods.

The situation is not helped much by the increasing competition between neighboring ports aimed at stealing transshipment traffic from each other. This is particularly worrying with publicly funded port investments. Clearly, there is a need for public policy intervention, at least in Europe, which needs to harmonize public spending among its member states, as well as to ensure free and fair competition among its ports.

\section{Differential terminal handling charges}

Big ships impose substantial demands on port capacity, without however paying commensurately for this demand. Moreover, I have calculated that the average container, arriving on a larger ship, takes more time to handle and store. In other words, port time per TEU is an increasing function of ship size (Fig. 4). The "supply chain" diseconomies of scale of larger ships, including their impact on shippers' inventory costs, start from the port. 
When it comes to berth utilization, whereas before we could accommodate three Panamax vessels along a one kilometer quay (i.e., three berths), today we can host there only two mega vessels of the latest generation (about $400 \mathrm{~m}$ long). Berth utilization obviously goes down. And all this would be fine, as long as carriers were bringing more traffic to the port with their larger vessels; but this does not happen either, and call size is only moderately correlated with vessel size. In such a situation, i.e., as carriers demand more berth space without bringing, proportionately, more traffic to the port, it would make a lot of sense to think of a different, revenue-neutral, terminal charging system, based on ship-dimensions rather than \$/box. [I have purposely chosen the word 'dimensions' rather than 'length,' for it is really bay size the critical factor for both crane and berth productivity. Obviously, it takes twice as much time to unload a container stowed below-deck in row 23, than one loaded on-deck in row 1; and this without considering, of course, the substantial costs of investing in ship-to-shore cranes with a 70-m outreach].

Could differential or variable pricing work, as a new system of Terminal Handling Charges (THC) aiming to offer carriers incentives to improve stowage planning? If the answer is 'yes,' this could offer carriers faster turnaround times (and time is money), and ports better berth utilization; a truly win-win situation. The issue of stowage planning, these days, is not a theoretical but a real and often troublesome one: Intra-alliance co-operation notwithstanding, in order to fill a larger ship today, a carrier calls at more loading ports than would be warranted by the economics of a hub-and-spoke system, picking up containers even at the last minute before departure. Stowage planning suffers as a result. As one terminal operator commented, [...] "we can do 150 moves per hour for a major independent carrier but only 100 for an alliance ship.” Slot swaps among alliance members do not make things easier either, with shippers booking containers with one company, only to find out that they landed at the other end on the ships of another carrier.

Variable terminal pricing, if it could ever apply in practice, should not become a form of yield management, so successfully, albeit also so frustratingly, applied in aviation, ${ }^{4}$ but also by the ocean carriers themselves through their market segmentation strategies: pricing strategies directly targeting the individual shipper and his willingness to pay for various logistical add-ons. As already said, variable pricing should be a 'revenue-neutral' charging system, aimed at promoting higher ship and terminal efficiency. After all, yield management could never succeed if applied by an individual port, for, solely by itself, a port has very little pricing leverage vis à vis the footloose container

\footnotetext{
${ }^{4}$ How many times haven't we tried to book a flight, only to see the price going up even while we were trying to do so...
} 
and its carrier. Moreover, any attempt to extract more revenue through yield management would be music to the ears of that port's competitors who in all likelihood will leave their own prices unchanged in order to capture the carriers' discontent (competing ports are facing a kinked demand for their services).

\section{Competition, transshipment, and the financing of ports}

Thirty years ago, forecasting port capacity was a fairly straightforward exercise, and a popular one at that, among students: population, GDP, and trade data, together with a simple regression model, would easily do the trick with some excellent results. It should be remembered that, in those days, demand for port services was more or less captive and a cargo destined for, say, Italy would in all likelihood land at an Italian port, as close as possible to the final consignee.

Two things have changed this picture since: containerization and the 'through transport' concept on the one hand, and the development of extensive land transport infrastructure on the other. Europe, for instance, dilapidated by a ruinous WWII, was being rebuilt, and what better way of doing this than developing your roads and railroads before anything else. If one were to take a cursory look at Europe's map today, what one would see wouldn't differ much from a nice dish of Italian spaghetti. Roads and railroads, together with European economic integration, free trade, and the abolition of national borders, opened up the market for port services. Before we knew it, any Asian cargo could in principle reach any European destination, passing through any gateway port around Europe. Port demand was no longer captive but stochastic, and ports started to compete fiercely for custom.

To do so, ports had to modernize and develop new capacity; often much more than what was needed. In the 1990s, I remember well, the northern range European ports (from Le Havre to Hamburg) had a collective excess capacity of about $40 \%$. Usually, port capacity is developed in big chunks, each time far ahead of existing demand. A combination of factors can explain this, ranging from the availability of easy and cheap public finance, to managerial egos and port managers' heartburning desire to leave their footprint in history... One more reason, of course, is economies of scale in port construction: apparently, it is much cheaper to build $2 \mathrm{~km}$ of quay rather than one.

Excess port capacity, over and above national demand requirements, is created for three more reasons. First is the economy of the scale mentioned above, as well as the infamous economic law of Jean-Baptiste Say according to which supply creates its own demand. In other words, once the port is there, the customer is bound to arrive. Unfortunately, this is not always so. The second reason is the footloose nature of the container and its carrier, who may switch 
ports at the whim of a moment, whenever port capacity is scarce and, as a result, the ship may have to wait. Finally, excess capacity is developed in order to capture transshipment traffic, i.e., somebody else's cargo! As a matter of fact, most of the competition taking place among ports today is for this type of cargo; to capture it, ports often underprice concession fees agreed with terminal operators, and terminal operators, in their turn, underprice terminal handling charges (THC) they charge to carriers (often through hidden or opaque discounts). ${ }^{5}$

Moreover, especially in ports where the management is responsible for its bottom line, more often than not the management tends to cross-subsidize footloose transshipment traffic with captive domestic traffic. In other words, domestic (national) cargoes are penalized through relatively higher prices, compared to transshipment cargo, in the management's anxiety to capture more of the latter. In a number of cases, some of which already heard in front of a judge (cf. Sarlis vs. MSC at the port of Piraeus), the preferential treatment of transshipment cargo goes beyond price and it involves other terms of service, such as berth allocations and time-windows. For a number of reasons, this is not right and I have always advised affected local shippers to present their case to the national competition authorities or, in case of complacency, directly to the Competition Directorate General of the European Commission.

And here is why this type of cross-subsidization, or price discrimination, between domestic and transshipment cargo is not right:

If sufficient domestic demand for port services does not exist, developing port capacity for transshipment purposes is risky business just because of the footloose nature of the container. Before you know it, you could find yourself with a ghost port in your hands, as it happened recently, for instance, at the Italian port of Taranto, when Evergreen decided to move to Piraeus, in spite of a 60 -year-long concession at the Italian port. Years back, I remember quite vividly the crisis that developed at the great port of Singapore, when Maersk decided to move to just around the corner, to the Malaysian port of Tanjung Pelepas.

In comparison to the economic impacts of domestic traffic, transshipment creates relatively less (local) value added. To draw a parallel, a port handling domestic cargo resembles a city-center hotel, where the visitor will most likely spend money on a number of activities (museums, restaurants, etc.), thus creating considerable value added for the city, vis à vis a highway motel (transshipment), where the traveler would stop there just for a sleep. I often hear my friends in Antwerp telling me that the port of Antwerp, as a result of its multipurpose/labor-intensive character, creates four times more value added

\footnotetext{
${ }^{5}$ By under-pricing, I refer to port dues and concession fees below the opportunity cost of port land.
} 
than Rotterdam, the latter port being a highly automated/labor-saving one. Thus, I am told, the Belgian taxpayer is much happier to pay taxes for port development than his Dutch counterpart, who has often questioned the social utility of developing more port capacity at Rotterdam. Exceptions to the above do of course exist, and Rotterdam is a good one: the port's value added is not created simply by the port itself, but by its port cluster, encompassing $50 \%$ of Europe's Asian and North American European Distribution Centers (EDC); a city $50 \%$ of whose inhabitants are holders of a foreign passport, just because of the port. But not all ports can realistically aspire to such an enviable situation, developed not today but over a period of 70 years of hard work.

Finally, publicly funded ports are developed exactly in order to have these domestic impacts on business and employment, rather than to steal (transshipment) traffic from their neighbor, particularly in economically interdependent geographical regions such as the European Union. The problem is aggravated when some countries spend public money on port development, while others finance ports privately (UK) and both compete in the same market.

Development of container terminal capacity, including its transshipment potential, will continue unabated; this is normal and, in the long-run, port capacity follows international trade growth. But with one caveat: this infrastructure should be priced (through the appropriate concession fees) in such a way so that investment costs are eventually recovered, irrespective of whether the proceeds from the concession remain with the port, or are returned to its financiers, the latter including also the government. In this way, it does not really matter who finances the investment, i.e., the public or the private sector, as long as the private investor principle applies, i.e., the terms of the financing are not very different from similar private arrangements and, as said, this means that pricing should aim at cost recovery.

Competition on infrastructure is indeed wasteful and governments, like recently that of Italy, have often argued in favor of centralized port infrastructure planning: something we used to do half a century ago, through the various National Port Councils. ${ }^{6}$ In today's Europe, however, something like this wouldn't only be wrong but, euphemistically, it would be unthinkable: To my mind, the best planners of all are the (well-regulated) markets themselves, accompanied by transparency in the financial flows between port and government.

The role of the public sector in financing container terminals should therefore be limited, and where it exists, or is necessary, it should take place on

\footnotetext{
${ }^{6}$ I remember an advocate of this policy, Francesco Mariani, the President of the Port of Bari, telling me recently that if a global carrier would like to come to Italy, he should only talk to the Minister and it should be the latter who 'should tell' the carrier which port he should call at!.
} 
more or less commercial terms. In this way, limited would also be the risk assumed by the public sector. Competition by neighboring ports, excess capacity, and similar concerns should lie only on the shoulders of the concessioners (terminal operators) who should themselves assume such market risks. It doesn't, in this way, matter if excess capacity is created. To put it bluntly, if things go well, we will all be raising a glass; if not, well, bad luck for the private concessioner. But the national taxpayer should not be bearing the costs (and risk) of private investments, benefiting private users.

The above is easier said than done. If the terms imposed on a private terminal operator, carrier, or other, are too onerous, in all likelihood he would be knocking on your competitor's door. And this is where public policy intervention is necessary. This can take only one form: an understanding that, no matter how terminal investments are financed, container terminals are private goods and their costs should be recovered through user charges; otherwise under-pricing is not much different than dumping, sanctioned in many other sectors, including shipbuilding.

But the story does not end at the financing of the container terminal itself. The ship must be able to approach a berth at the terminal, and the container needs to eventually reach the motorway from the container yard. Who should pay for these investments? Is a 16-m-deep approach channel and turning basin a public or a private good? Clearly, neither is really meant for my little, 3-m, fishing boat. Is a road that connects the terminal with the motorway system a public or a private investment? I could indeed take my bike and ride to the waterfront for some ship-spotting; but clearly again, this was not exactly the purpose the road was built. My views on these aspects are quite clear: these are private investments benefitting identifiable users and, thus, cost recovery should apply here too through user charges.

\section{Public involvement in the port industry}

Public involvement in ports, usually through a statutory body known as Port Authority, can take various forms, ranging from the mere ownership and leasing of port land and basic infrastructure (landlord ports), to the provision of all portrelated services, notably cargo-handling (service ports or comprehensive ports).

In the research I carried out for the International Labor Organization (ILO $1995 \mathrm{~b}$ ) on the reforms taking place in the world port industry, it came out that in most ports around the world, wet areas (63\%) and quays (76\%) were in public ownership without competition, while the operation of quays and terminals was fairly evenly distributed between the public and the private sector (Table 1). 
Table 1: Ownership and control of ports

\begin{tabular}{|c|c|c|c|c|c|c|}
\hline \multirow{2}{*}{ Infrastructure } & \multirow{2}{*}{$\begin{array}{c}\text { Public no } \\
\text { Competition } \\
\%\end{array}$} & \multirow{2}{*}{$\begin{array}{c}\text { Public } \\
\text { Competition } \\
\%\end{array}$} & \multirow{2}{*}{$\begin{array}{c}\text { Private no other } \\
\text { Competition } \\
\%\end{array}$} & \multirow{2}{*}{$\begin{array}{c}\text { Private } \\
\text { Competition } \\
\%\end{array}$} & \multicolumn{2}{|c|}{ Mixed (\%) } \\
\hline \multirow{2}{*}{\multicolumn{7}{|c|}{ Quays }} \\
\hline & & & & & & \\
\hline Ownership & 63 & 9 & 7 & 1 & 12 & 8 \\
\hline Operations & 32 & 8 & 8 & 20 & 23 & 9 \\
\hline \multicolumn{7}{|l|}{ Wet area } \\
\hline Ownership & 76 & 5 & 7 & - & 1 & 11 \\
\hline Operations & 55 & 4 & 7 & 8 & 8 & 18 \\
\hline \multicolumn{7}{|c|}{ Superstructure/equipment } \\
\hline \multicolumn{7}{|c|}{ Container cranes } \\
\hline Ownership & 28 & 5 & 7 & 24 & 13 & 23 \\
\hline Operations & 24 & 4 & 9 & 28 & 12 & 23 \\
\hline \multicolumn{7}{|c|}{ Container equipment } \\
\hline Ownership & 28 & 4 & 9 & 33 & 9 & 17 \\
\hline Operations & 23 & 4 & 11 & 36 & 12 & 14 \\
\hline \multicolumn{7}{|l|}{ Bulk equipment } \\
\hline Ownership & 19 & 4 & 11 & 31 & 20 & 15 \\
\hline Operations & 16 & 3 & 12 & 35 & 17 & 17 \\
\hline \multicolumn{7}{|c|}{ Sheds and warehouses } \\
\hline Ownership & 44 & 7 & 4 & 8 & 31 & 6 \\
\hline Operations & 24 & 5 & 7 & 21 & 35 & 8 \\
\hline \multicolumn{7}{|c|}{ Facilities and services } \\
\hline Pilotage & 5 & 52 & 3 & 28 & 11 & 1 \\
\hline Towage & 12 & 29 & 4 & 20 & 31 & 4 \\
\hline Mooring & 5 & 35 & 3 & 23 & 29 & 5 \\
\hline Ship-repair & 7 & 5 & 8 & 51 & 11 & 18 \\
\hline Bunkering & 13 & 3 & 7 & 60 & 4 & 13 \\
\hline Adm. services & 44 & 4 & 4 & 19 & 17 & 12 \\
\hline Other services & 31 & 5 & 5 & 20 & 27 & 12 \\
\hline
\end{tabular}

Source IL0 (1995b)

Often, State intervention in ports may involve port strategy, management, and operations, but the state can also intervene in more indirect ways, e.g., by planning and coordinating port development among national ports, financing investments, or determining the ports' regulatory framework.

Table 2 affords some insight into the methods governments use to control port authorities. As can be seen, approval of "budgets" and "investment plans" are the most common means of control. In South East Asia, governments often resort to the approval of "expenses reports," while profit targets can also be set. Profit targets are not used, to any noticeable extent, in Latin and Central America. Several reasons can be put forward for the public sector's involvement in ports:

\section{Military protection}

Many major seaports are located close to national borders and might thus be vulnerable to attacks from the sea. In older times, most ports were for that 
Table 2: Government control of port authorities

\begin{tabular}{lcccc}
\hline & $\begin{array}{c}\text { Global } \\
(\%)\end{array}$ & $\begin{array}{c}\text { Europe } \\
(\%)\end{array}$ & $\begin{array}{c}\text { South and Central } \\
\text { America (\%) }\end{array}$ & $\begin{array}{c}\text { South East } \\
\text { Asia (\%) }\end{array}$ \\
\hline Expense reports & 32 & 32 & 25 & 55 \\
Budgets & 47 & 47 & 37 & 50 \\
Profit targets & 28 & 21 & - & 40 \\
Investment plans & 44 & 37 & 12 & 10 \\
Others & 8 & 5 & 12 & 10 \\
\hline
\end{tabular}

Source IL0

Percentages do not tally due to multiple answers

reason military protected areas. Even nowadays, a number of commercial ports around the world still dedicate a part of their infrastructure to naval bases.

\section{Expropriation of sites}

In many cases, ports have to extend into the water where, usually, there is no provision for the expropriation of sites. In most countries, people can acquire legal rights to territory or land and can subsequently exclude others from their use. This is never the case for water or aquatory, the more so when most countries recognize a general right of passage, or free navigation, to which unauthorized port structures could be considered as obstructions (Goss 1993).

\section{Economic protection}

As major ports are usually gates to international trade, they may afford governments a convenient means to implement import-restricting policies, aimed at protecting domestic markets. Import restrictions can be effected by the erection of tariff and/or non-tariff barriers. The latter can take many forms and are usually more difficult to detect and quantify. High port dues and terminal handling charges, long turnaround times and inefficient ports in general could be seen as constituting effective non-tariff barriers to trade. It has sometimes been argued that import-competing domestic producers have strong vested interests in the continuing existence of inefficient ports, as this offers them effective protection. Such producers could also be effective lobbyists and influential members of pressure groups that resist port reform. ${ }^{7}$

\footnotetext{
${ }^{7}$ During my 4-year term as president of the Italian port of Brindisi, I had the opportunity to witness first hand another type of resistance to reform. In the supervisory bodies of portstakeholders, known as port committees (Comitato Portuale), sat such persons as representatives of shipping agents; shipowners; port operators; municipal/regional "gauleiters," i.e., 'clients' of the port who often had not only a conflict of interest between their supervisory role and that of a port client, but also every interest in maintaining the status quo, which was affording them effective protection from outside competition. As the red line between 'supervision' and 'management' is not always as clear-cut in Italy (and of course in other countries of the European
} 


\section{Natural monopoly}

Ports are often referred to as the classic example of the so-called natural monopoly case, whereby possible market failure can justify government intervention (Baumol 1977; Shirley and Nellis 1991; Mosca 2008). Under certain conditions (level of demand, cost structures, and technology), a market with two or more firms can produce sub-optimal economic outcomes (for example, a certain port may be too small to have two tug operators), whereas a single firm might produce the required output more efficiently. For this reason, governments may, at times, decide to move away from a multi-firm competitive environment (competition "in" the market), towards a monopolistic, albeit regulated, situation (competition "for" the market) arranged through competitive tendering.

I have always argued that such public intervention in commercial decisions is wrong. And it is wrong for two reasons. First, the (often) widespread corruption in the public sector may result in 'photographic' tenders favoring the local incumbent, effectively shutting-off international or even national competition. It is not uncommon for public tenders to end up with only one interested bidder, while the correlation between 'single-bid' contracts and corruption in the public domain is not passing unnoticed either (Fig. 5). Finally, the openingup of the market for public contracts is one area where WTO is dragging its feet for years now without much progress. Second, governments, and the public administration by and large, are the least competent actors to decide on 'market size,' or on the financial ramifications for private firms who would like to take calculated risks and enter the market. ${ }^{8}$ This is because governments lack both the information required for such decisions (a typical example of asymmetry of information), and the legitimization to decide themselves on the fortunes of

\section{Footnote 7 continued}

south) as it is in northern Europe, this situation often frustrated my decisions, bringing them to a grinding halt, to the detriment of the general interests of the City and of the wider port community these stakeholders were supposed to safeguard. Two cases are typical and I would be amiss not to mention them here. (a) When I brought Grimaldi Lines to Brindisi (by far Europe's biggest shortsea-shipping and multimodal operator), certain local agents of competitor lines mounted a war against the newcomer, lobbying travelers not to use Grimaldi ships because he would eventually monopolize the traffic [...] and this would result in higher ticket prices in the future! (b) When I decided to develop the cruise business in the port, tendering a beautiful berth overlooking our magnificent medieval castle (Castello Alfonsino), a local cruise agent (and member of the port committee) went live on television, expressing his concerns [sic] about the health [...] of our American and Canadian visitors, who would disembark in the vicinity of a coal berth! Interestingly, as soon as he managed to block the project through a legal injunction, he immediately berthed the cruise ships he himself was representing to the very same spot!.

${ }^{8}$ A notorious case, immediately overruled by the State Council, was the communist Greek government's decision, in 2016, to limit the number of national TV stations to 4, on arguments based on the 'financial survivability' of broadcasters, given the size of the advertising market... 


\section{They go together}

Corruption perceptions index and single-bid contracts in European countries, 2015

O Rest of Europe Central and eastern

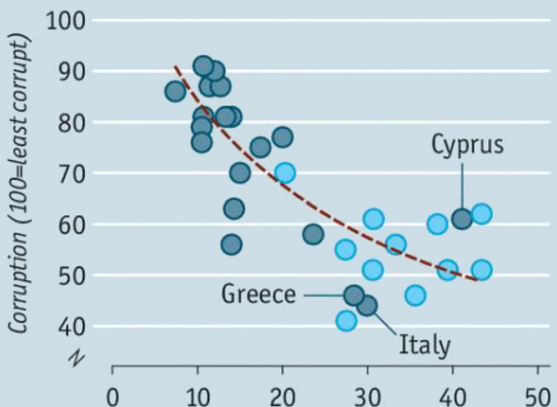

Share of government contracts ${ }^{*}$ with one bidder, \%

Sources: Tenders Electronic

Daily; Transparency

International; certain threshold included representing $26 \%$ of all procurement in the EU

Fig. 5: Corruption and single-bid contracts

Source The Economist 2016

private risk-takers. Instead, the role of the public administration ought to be to set the rules of the game; determine the conditions and quality of service it requires (including any Public Service Obligations); and then leave it up to the private sector to decide for themselves if the market is big enough, if they see profit prospects, or if they would like to go bust; but this ought to be 'their' decision, because it is 'their' money and 'their' neck on the block.

\section{Public goods}

Among the many functions of public port authorities, whether (semi)autonomous or centralized, is the provision and maintenance of the port's basic infrastructure, such as breakwaters, approach channels, turning basins, rail/ road connections within the port, and navigational aids. Apart from the general public's interest in the safety of ports, many of the services such infrastructures provide can clearly be considered as falling within the ambit of a public good, in the sense that no particular user can be excluded from their use if he is not agreeable to share in the cost of their production; a situation often referred to as the free rider problem. Furthermore, services such as those provided by, say, breakwaters and navigational aids can be considered as collective consumption 
goods (Shoup 1969) in which case, and up to a point, the total cost of producing them does not vary in relation to the number of their consumers. Finally, a number of port services can be considered as non-rival in consumption (Musgrave 1969), given that user A's demand does not reduce (compete) that of user B. Those port services that qualify as "public goods" ought to be provided by some public authority, although provision should not be confused with production: the latter could be entrusted either to the public or to the private sector, depending on considerations of economic efficiency. This is notably the case of the nautical-technical services (towage; pilotage; line-handling), which are increasingly brought in the ambit of the private sector, albeit under strict regulatory control.

\section{Financing}

The rapidly changing cargo-handling technology; the increase in the size of modern container vessels; the limitation in the number of direct port callscoupled with the expansion of main-line/feeder networks; and the growth of international trade have resulted in numerous port expansion/modernization programs, generally requiring substantial capital outlays and invariably leading to regional overcapacity. Regional port competition and the need of ports to turn ships around as quickly as possible, and within pre-specified time-windows, is an additional contributing factor to regional port overcapacity (Haralambides 2002). This said, however, overcapacity should also be seen, in all honesty, as a necessity, i.e., as an unavoidable cost, rather than as an indication of inefficiency: Through simple queuing theory, it can be easily shown that, once port utilization reaches $70 \%$, congestion starts to set in and this is not acceptable among competing ports where ships must be turned around as quickly as possible and within a certain time-window.

These investments often exceed the financial capabilities of the public sector, thus making the case for private sector involvement; a development that would make sense anyway, given that, increasingly, ports, particularly container terminals, are losing the public good character, becoming private goods, whose services ought in principle to be paid by their user rather than the general taxpayer.

However, often, in spite of its abundant financial resources, particularly those of global terminal operators (GTO), ${ }^{9}$ the private sector may be reluctant to invest in ports, particularly when capital outlays have to be made in uncertain institutional and regulatory frameworks, or through usually frontloaded agreements (concession contracts) that cannot guarantee positive financial returns in the longer term. On the other hand, as government objectives usually

${ }^{9}$ Such as Hutchinson Port Holdings (HPH); PSA; DP World; APM Terminals; ICTSI. 
extend beyond considerations of short-term financial profitability, concerning rather the maximization of long-term economic welfare, a number of port development projects that might be deemed unprofitable by the private sector can be of cardinal importance to the government. Thus, the success of any public-private partnership (PPP) is in being able to strike the right balance between the two: In other words, affording the private sector an acceptable return on investment (RoI), on an opportunity cost basis-i.e., a return as good as that of the investor's second best investment, while keeping the bulk of the generated economic rent ${ }^{10}$ in the hands of the public sector.

\section{National/regional economic development}

In addition to their main functions as interface, storage, and distribution points, efficient ports also function as growth poles, attracting new activities and stimulating trade (Rimmer 1984; Haralambides 2012). In this way, and apart for their obvious direct contribution to GDP growth and regional development, the indirect contribution of ports to the economy is also substantial, given their importance for the competitiveness of the country's export industries. State intervention is thus often justified on the grounds of these "not solely commercial" objectives of ports. The costs of such macroeconomic objectives of the State, however, often manifested in departures from economic efficiency in a strict sense, ought to be borne by the State itself, and it would be unrealistic to expect private investors (only interested in RoI) to share in them. Again, if private investment is deemed desirable, concession contracts should be drafted in such a way as to strike a balance between public welfare objectives and private profitability ones.

For instance in Japan, apart from the direct financial returns of port operations, port development is appraised on the basis of its contribution to the social and economic development of the region and the nation. Port development plans (masterplans) are thus adjusted to and included in the country's regional development plans, while ports are managed and administered by public sector bodies. Among other advantages, this approach helps in rationalizing port investment; avoids duplication and wastage of scarce resources, due to excessive competition in an industry predominantly described by increasing returns to scale and sunk costs and, finally, it helps in optimizing the spatial aspects of port investments, so that they can tie-in meaningfully with the rest of the country's infrastructure.

However, as I argue below, the influence of this statist approach to port management is fading out today in most parts of the world. Its problem is in

\footnotetext{
${ }^{10}$ It should not be forgotten that, in spite of intra-port competition, a port will always have a 'captive audience,' and thus a significant market power.
} 
limiting port management autonomy at a time when ports are expected to become new-business developers and compete for traffic internationally. This new role of ports, and related governance models, is finding strong support at least in Europe (ESPO 2010), vis à vis earlier (public) port governance models that tended to limit the functions of a port authority to those of the harbor master's office. $^{11}$

The realization of indirect macroeconomic objectives may indeed generate numerous benefits for the region or the country by and large, but these do not necessarily produce visible financial rewards for the ports concerned. Thus, the efficiency and productivity of the latter might, at first sight, be considered as disappointing and inferior to that of comparable privately owned enterprises with clear-cut financial objectives (e.g., UK ports), or compared to ports which have been centrally prioritized on the basis of macroeconomic objectives. Moreover, such a 'central' prioritization (planning) is not void of strong resistance by affected local communities, whenever the fortunes of one (prioritized) port are at the cost of another. Few would argue against the benefits from looking at ports as a 'port system'; these have been described above, in the case of Japan. But the objectives of such a regional approach to port development should be to enhance regional cohesion, thus leading to a more balanced development across the region. Thus, together with prioritization, a system ought to be found, and agreed upon, to distribute the fruits of this planning policy, as equitably as possible, also among the 'unlucky' ports, their cities, and citizens. Otherwise, local political opposition could be so strong as to frustrate any central attempt to 'allocate roles' among ports. ${ }^{12}$

\footnotetext{
${ }^{11}$ I hope the exaggeration of the witticism would help in driving the point home.

${ }^{12}$ My 'Brindisi experiences' could help, here too, in order to drive this point home. It seems that due to some 'unwritten law,' going back for decades, Brindisi -maybe one of the most backward cities in Europe- has been condemned to the handling of coal, also with cargo-handling and inland transportation techniques which have a lot to be desired, compared to modern cargo-handling, storage, and coal distribution practices. The environmental impacts from the (improper) handling of coal are only too well known to be repeated here. As a result, the citizenry is constantly expressing strong concerns, often quite vociferously. At the same time, the more 'sexy' types of port traffic, such as cruise and ferry, have moved almost exclusively to its new competitor, the port of Bari, a city located just $100 \mathrm{~km}$ to the north, and the seat of the regional government. Thus, for decades, the port of Brindisi has been in a state of heart-breaking decay. As soon as I moved in, I made it clear to all that Brindisi was open to business. The first big success came with the arrival of Grimaldi Lines. Soon after this, I was 'summoned' to the regional headquarters in Bari for a "meeting." The punch line of that meeting was to tell me that I should be 'careful' with my decisions, and with my talking to shipowners, for Bari was living from its port and they were not as lucky [sic] as Brindisi to have so much coal! [sic]. At the time of writing (2017), the two ports had been integrated by "government decree"; or rather, Brindisi was taken over by Bari. The result? The handling of coal stayed at Brindisi, while the money from the handling of coal 'moved' to Bari; a great plan no doubt!.
} 
As said, a statist approach to port management reduces port authorities to mere administrators. However, if this is the objective of the State, then it should be spelled out clearly in the relevant port laws, rather than expecting ports to function under commercial management principles, often with financial targets imposed on them. There is no worse thing than responsibility without authority, and governments, as well as public organizations, fortunately start to realize that you can't have your cake and eat it as well.

\section{Public retrenchment from the port industry}

\section{Government retrenchment}

It is sometimes argued that policies of public sector retrenchment, together with the encouragement of more private sector initiatives, are rooted in ideological origins. However, regardless of how true this opinion may have been in the past, current economic and political developments worldwide can no longer support its validity. Instead, the reasons for explaining the widespread popularity of the various divestiture programs are to be found, among others, in the increasing economic interdependency among nations and the trend towards the globalization of all forms of economic activity.

Regardless of ideological postures and doctrines, an increasing number of governments (and ordinary citizens) realize that it is no longer possible to isolate their economies, or insulate them from external economic influences and shocks. Even if this was still possible, such a policy's effectiveness towards increasing growth and industrialization would be more than doubtful, at least today.

In many countries, governments have become painfully aware of the inadequacy of their state-owned enterprises (SOE) in an environment of increasing international interdependence and global competition. Marketoriented policies are thus becoming more and more popular in order to reap the benefits of higher efficiency and productivity, and to reduce the financial and administrative burden SOEs often impose on their owner, the state.

High levels of staffing, ${ }^{13}$ together with the absence of risk assessment in economic decisions; the lack of accountability for economic performance (staff assessments); the impersonality of operational structures; and a missing sense of belonging and achievement can very effectively remove employees' natural drive for initiative, innovation, and higher efficiency, consequently resulting in very low (and sometimes even negative) port labor productivity. This is one of

\footnotetext{
${ }^{13}$ If one is unfortunate enough to have to find his way through the corridors of a government ministry, somewhere in Spain, Portugal, Italy, or Greece, he couldn't fail to notice filing cabinets placed in corridors, often against fire-fighting regulations, so that more space is created inside the offices to accommodate an increasing number of seemingly working people.
} 
the major driving forces behind the various divestiture programs at ports throughout the world.

However, in the case of ports in particular, it would be fundamentally wrong to believe that the above are the only factors accounting for the low labor productivity of the public sector, and comparisons between different countries or between different sectors of the same economy should, therefore, be contemplated with extreme care. Labor productivity ought not to be measured only as "output per man/hour" or "tons handled per gang-shift," as it is sometimes the practice in many ports, but as output per man/hour produced with a certain stock of fixed capital of a given technology and operational characteristics. Thus, differences in labor productivity between the private and the public sector could be explained equally well by the fact that the level of fixed capital formation in the public sector is frequently inadequate or obsolete, due to scarcity of financial resources, budgetary constraints, and the economic priorities of the government.

Notwithstanding this, employment in most state-owned ports, and to that effect in the wider public sector by and large, is usually characterized by high levels of staffing. ${ }^{14}$ Many times, this is not only the result of the government's employment creation policy-particularly in developing countries with rapidly growing populations and an anemic private sector-but also of the fact that, through its permanency of employment, fringe benefits, and stability of income, employment in the public sector is often an arduously sought after objective, many times pursued through systems of 'political clientelism.'

However, large-scale employment in the public sector creates inelastic government expenditures, it increases the Public Sector's Borrowing Requirements (PSBR), and it may lead to inflation and high interest rates. In their turn, the latter can hinder the private (domestic and foreign) sector's propensity to invest and subsequently result in less output, employment, and growth. Additionally, inelastic government expenditures can reduce the effectiveness of fiscal policy as a tool of economic stabilization. The latter (at least nowadays) is almost invariably a pre-condition for the successful implementation of structural adjustment programs and often the reason for the divestiture plans of the government.

\section{Port management challenges}

The capital intensity of liner shipping and the need for maximum capacity utilization and fast turnaround times, in order to achieve adequate rates of

\footnotetext{
${ }^{14}$ I witnessed with my own eyes, at a major port of a certain Asian country, 10 dockers washing a container, all holding on to the same water hose! Let it be noted too that they were casual workers, while the registered ones were watching them from the bridge, blissfully smoking their cigarettes.
} 
return on investment, have increased pressures on ports for further improvements in labor productivity and operational efficiency. In its efforts to adjust to the new demand requirements, the port industry has also become a capitalintensive one, requiring massive investments in port infrastructure and sophisticated cargo-handling equipment. In this way, containerization and the cargo-handling techniques it induced have had an equally profound impact on port employment. As with all other capital-intensive innovations, containerization substituted capital for labor and thus resulted in substantial redundancies, accompanied however by remarkable increases in labor productivity $^{15}$ and port worker salaries (Fig. 6).

However, port performance and labor productivity measures observed in various ports around the world still demonstrate substantial differences from one port to another, even within the same region. With regard to container traffic, for example, container-handling productivity among western European ports in 1991 varied from 30 moves per hour/crane down to 14 moves per hour/ crane. In an Asian port in 1992, 458 containers were handled in $3 \mathrm{~h}$ and $15 \mathrm{~min}$ to and from a containership and the vessel stayed at berth for less than half a day, while in another port in the same region, to handle the same number of containers the ship had to spend 2-3 days in port. The gap in labor productivity between ports can also be substantial. In a major far-eastern port in 1992, about 200 million tons of cargo were handled with a total of 7200 employees, while in another port of a developing country in the same region, 52,000 people were employed for a total throughput of about 150 million tons of cargo. ${ }^{16}$

High costs, poor services, and low efficiency and productivity appear however to be only the symptoms of the problem. An UNCTAD survey carried out in four African countries (Ivory Coast, Ethiopia, Kenya, and Senegal) showed that many port problems were not of a technical nature and that investment in modern port facilities had been generally good; apart from minor omissions, there were no cases of serious infrastructure defects.

It was thus evidenced that although many ports are in possession of the right infrastructure and necessary equipment, what they lack is effective management, or modern management knowhow. In many instances, basic management principles such as those of clear description of objectives and area of authority and responsibility, accountability and control, adequate rules and regulations,

\footnotetext{
15 A century ago, New York Harbor employed 40,000 longshoremen, who unloaded ships with hook and sling and brawn. Today, the entire workforce is just under 3400 longshoremen, many perched behind the controls of cranes and straddle carriers (New York Times 2017).

${ }^{16}$ As already noted above, comparisons of labor productivity should be attempted with utmost caution. Labor productivity is a function of the existing capital equipment and if the latter is inferior or obsolete, as it often is in developing countries, labor can produce only that much with it.
} 


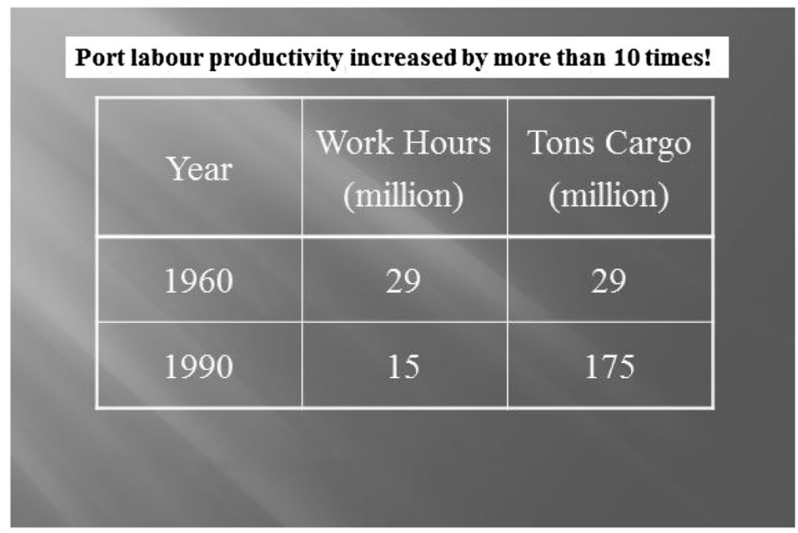

Fig. 6: Port work-hours and tons handled in the US west coast Source US west-coast longshoremen's union

good statistical and information systems, financial accounting and cost control, quality control, human resource development, appear to be missing. ${ }^{17}$

Yet, the management ability of port managers, including those in developing countries, should not be underestimated. A cursory look into the management techniques of most ports today will immediately show that the above-mentioned managerial skills are rather well known to most port managers and many of them have already been in place. Modern port management knowledge has in fact been well spread in many developing countries through various training activities during the last decades, and it is not uncommon today to find many port managers in developing countries that have been trained abroad in modern management techniques. In many ports, the problem seems not to be the lack of modern management knowhow, but rather the lack of its effective implementation. Managerial measures do not thus touch the root of the problem which, in most cases, seems to be institutional.

More often than not, the interface between the government and the port is too heavy. As a result of unnecessary bureaucracy and state intervention, ports have many times been prevented from carrying out their management streamlining efforts, as well as react to the needs of the market. Furthermore,

\footnotetext{
17 As soon as I moved in at Brindisi, the standard question each and every staff member of the port authority asked me was could you please tell me what is my job? People were being reallocated from one department to the other without notice or motivation, at the spur of a moment; the port's statistical information system was run, quite independently and without any control, by an external private company; quality control was an unknown concept; and a human resources officer did not exist. Immediately, I started a process of internal reorganization, including a system of staff assessments. Interestingly, it was the very same people who asked me to define their job, who fought the most against staff assessments!
} 
the lack of competition often results in a negative service attitude within the port. Because of the "soft budget constraint" and the frequent low-interest government loans or subsidies, the "opportunity cost of capital” is a principle virtually unknown to many port managers. This may explain why cost control is often a low-ranked priority in many public ports. Besides, port tariffs are often state-controlled and do not correspond to market prices, something that affects adversely the management's motivation to seek cost reductions.

Thus, investments are not always made in time and when they are, they are not market-oriented or cost-effective. Decision makers may be more responsible for political or administrative priorities rather than commercial ones. The difficulties connected with the quality of port decision-making are often due to the excessive distance between the place where the problem arises and the place where the solution is worked out. Centralized public port administrators rarely make decisions without consultation at a ministerial level and they often have a very relaxed attitude regarding commercial matters. ${ }^{18}$ In the UNCTAD study mentioned above, it was shown that good intentions to improve port performance had, in most cases, run into problems of implementation or were over-laden with subsequent controls, ${ }^{19}$ combined with a distinctive unwillingness of the middle ranks of central government to delegate authority.

\section{Port labor issues}

In the earlier days (up to the beginning of the 1960s) general cargo, carried by liner shipping, was transported, in various forms of packaging (pallets, boxes, barrels, crates, slings), by relatively small vessels, known as general cargo ships. These were twin-deckers and multi-deckers, i.e., ships with holds (cargo compartments) in a shelf-like arrangement where goods were stowed in small pre-packaged consignments (parcels) according to destination (Fig. 7). This was a very labor-intensive process and, often, ships were known to spend most of their productive time in port, waiting to load or discharge. And although seafaring was great fun in these days [sic], the same cannot be said for casual port work which was rather ill-considered and looked down by society. As a

\footnotetext{
${ }_{18}$ All of my predecessors at Brindisi were quite versed in finding their way to the right ministerial office, or pick up the phone and call the Minister, but they wouldn't speak a word of English. A marketing and communications department did not exist at the port authority at the time I stepped in.

19 The construction of the new passenger terminal in Brindisi was delayed for months because the director of the regional branch of the Ministry of Cultural Heritage thought that the logo design on the roof of the terminal was a bit too high [sic] and this would spoil the historical landscape view of Brindisi! The local landscape architects objected too albeit for a different reason. Forty years ago, in the area of the intended terminal, nowadays right in the middle of the port, there used to be a beach and, thus, they thought we should keep it this way notwithstanding the fact that, today, no one would even dream of swimming there even if one could!.
} 


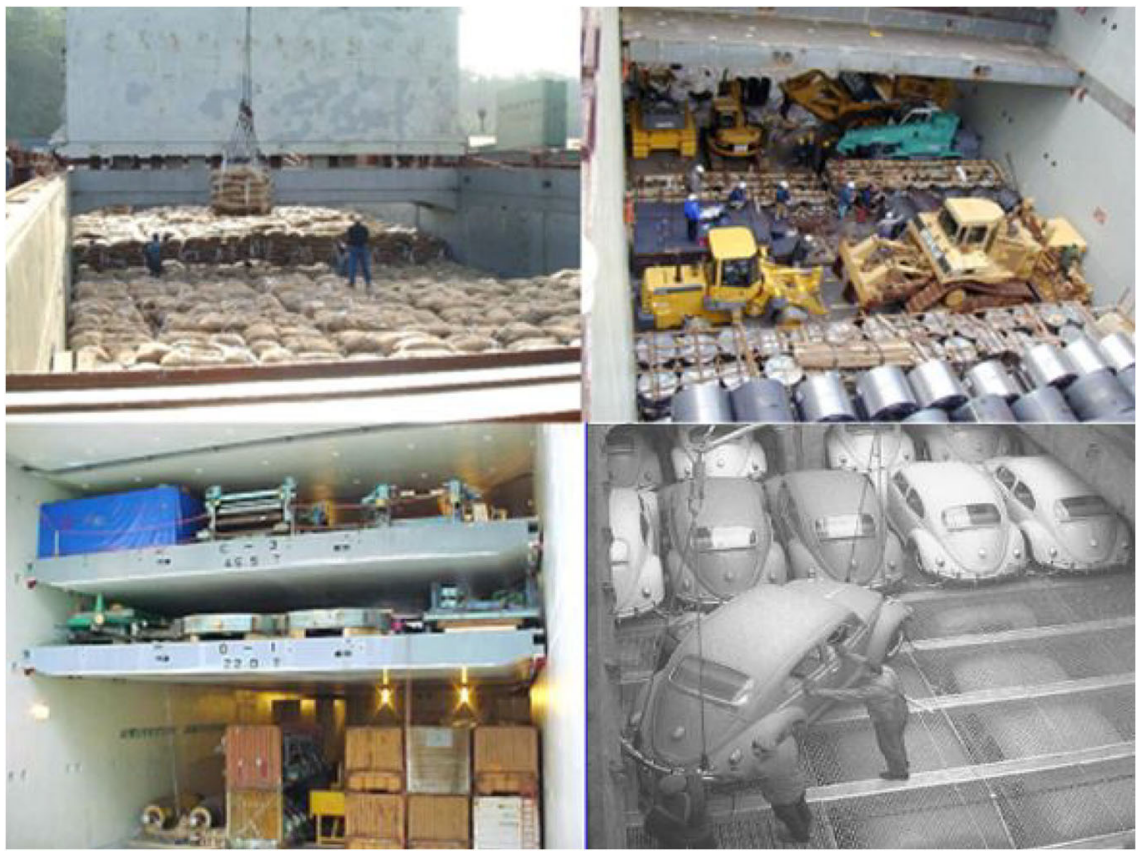

Fig. 7: Multipurpose, general cargo vessels

result of the unpredictability of port work, port management could not possibly employ permanent staff, paying them while idle, and waiting for the next ship to arrive. Yet, the cargo needed to be unloaded quickly, so that produce did not spoil. Labor was thus casual, i.e., employed for as long; as much; and whenever required. Recruitment was very different too. Each morning, a number of dockers would present themselves to a union foreman, often a mobster, and he, on the basis of certain 'criteria' that had more to do with natural selection rather than anything else, would thumb-in the youngest, the strongest, the favorites of the union, or those prepared to return a kickback to the union. ${ }^{20}$ The rest would return to their 'locales' [sic] and indulge in whatever it was they were indulging in.

Congestion was also a chronic problem in most ports, raising the cost of transport and hindering the development of trade. Equally importantly, such delays in ports made ship arrivals (and consequently port work) erratic and

\footnotetext{
${ }^{20}$ To indicate this 'preparedness,' the latter dockers used to put a toothpick behind their right ear. A beautiful account of the "waterfront" can be watched in Elia Kazan's 1956 masterpiece "on the waterfront," with Marlon Brando, or Mike Newell’s 1997 drama “Donnie Brasco," with Al Pacino and Johnnie Depp.
} 
unpredictable, ${ }^{21}$ obliging manufacturers, wholesalers, and retailers to keep large stocks. As a consequence, warehousing and carrying costs were adding up to the cost of transport, making final goods more expensive and, again, hindering the development of international trade.

Containerization and the introduction of the new cargo-handling techniques in ports have changed all this. Around the world, the port industry has invested a lot in order to cope with the new technological requirements. Modern container terminals-and corresponding cargo-handling equipment-have been built and new, more efficient, organizational forms (including privatization) have been adopted in an effort to speed up port operations. Operational practices have been streamlined; the element of uncertainty in cargo flows largely removed; forward planning has been facilitated; port labor regularized; and customs procedures simplified. These developments took place under the firm understanding of governments and local authorities that ports, now, constitute the most important link (node) in the overall door-to-door supply chain and thus inefficiencies (bottlenecks) in the port sector can easily whither all benefits derived from economies of scale in liner shipping and in global supply chain management.

As said, the above developments, notably the predictability of ship arrivals and of port work - and consequently of port labor requirements, have provided an important stimulus for the registration of port workers.

Moreover, the capital intensity of the new cargo-handling technologies, together with carriers' ability to now plan a reliable shipping network, have resulted in a need for more intensive port capacity utilization. This has been achieved mainly through the extension of working periods, which in many ports was done through the introduction of shifts. As the new technology required also a skilled workforce, the need for the regularization of employment relations was apparent, as there was no way casual labor could provide the adequate, responsible, and skilled manpower, necessary to move cargo safely and efficiently through a modern port using advanced equipment (Couper 1986). Regularization of employment, finally, provided casual workers with some form of guaranteed employment or income and it was thus strongly supported by trade unions, which often made it an explicit objective in their negotiations concerning the social impacts of the introduction of the new cargo-handling methods. ${ }^{22}$

\footnotetext{
${ }^{21}$ Delays in one port propagate onto others with a cascading effect.

22 It should be noted that, although port working periods have been extended to 'around-theclock,' the number of workers has been reduced dramatically due to automation and mechanization (see above). As a result, in many ports, strong unions have set up 'funds,' replenished regularly by carriers on a $\$$ /ton-handled basis, meant to compensate port workers for the fewer hours that they now have to work! At the time of writing, at the port of New York and
} 
The necessary adjustment of manning levels, however, was often prevented or delayed due to pressure from the affected labor, often represented by powerful trade unions. On the one hand, port workers had an interest in the introduction of modern cargo-handling techniques, as this reduced their hard physical work and afforded them regular employment. Besides, unions realized that the introduction of the new techniques was necessary to secure the competitive position of the port, which directly affected their long-term employment prospects. On the other hand, however, workers feared that the new technologies would lead to a considerable reduction in employment (in which they were right), and this has brought many of them to resist technological change. Already in 1969, there were refusals to operate new types of equipment, and shift systems and gang sizes were not reduced in line with the changed needs (Couper 1986).

An additional reason for the resistance of port labor to change relates to the "through transport" concept and the door-to-door possibilities that containerization now afforded. In other words, a considerable part of what was previously considered as 'port work' was now increasingly shifting to areas outside the port domain. This development has especially to do with the stuffing and stripping of containers that can now be performed at the consignor's/ consignee's premises by the latter's own staff. Even when this is not the case, containerization often allows the detachment of staffing and stripping activities away from the usually congested "waterfront" and its "rigid" and strongly unionized labor, towards Inland Container Depots, where ample and cheaper space is available, often conveniently located close to main road and rail junctions. By-passing the waterfront in the stuffing and stripping of containers, and thus having them ready in port to be swiftly handled by automated equipment, further increased, in its turn, the predictability and reliability of cargo movements, enabling manufacturers and traders to reduce high inventory costs through the adoption of flexible Just-in-Time and Make-to-Order production technologies.

From the point of view of port labor, this development further exacerbated workers' misgivings with the new technology: The well-proclaimed advantages of containerization were not localized but dispersed throughout the regional/ national economy and, thus, not immediately visible or directly beneficial to the workers who had contributed to their accomplishment. In the end, as port management needed the co-operation of workers, in order to implement the new technology successfully, certain promises regarding job security and

Footnote 22 continued

New Jersey, this flat rate amounts to $\$ 5 /$ ton and in view of that port's substantial throughput, the fund's 'welfare' is not difficult to calculate... 
financial compensation were made to unions, applicable to the fortunate workers who would remain employed after the necessary redundancies.

In many countries, all work falling under a certain definition of "dock work” and taking place within a certain statutorily defined "port area" is restricted to registered workers who sometimes have the sole legal right to carry it out, often organized in labor pools, even when they do not possess the necessary skills. This situation often leads to ghosting, where non-registered dock workers, some employed directly by port operators, carry out whatever work is necessary, while registered dock workers are paid in effect to watch the non-registered employees, with the necessary knowhow, actually carrying out the work. ${ }^{23}$ For example in one Asian port, a gang of 57 people was deployed to pack and unpack containers, although this was actually performed by four casual workers while the remainder looked on. The failure to adjust workforce levels to changing employment needs disadvantages many ports in (low wage) developing countries with total labor costs well above those in developed ones.

This relatively protected position of registered port workers can be seen as one of the reasons why they often enjoy higher wages than those paid for comparable jobs elsewhere in the Economy. ${ }^{24}$ Some observers argue that this privileged position has finally resulted in a negative attitude of the general public and other unions towards port workers.

Sometimes, pressure to maintain old fashioned manning levels comes also indirectly from the government, which is reluctant to face the financial and political consequences of labor force reductions that can lead to substantial compensation payments to those leaving the industry, or even disruptions to foreign trade. Furthermore, and contrary to most developed countries where one of the prime objectives of management is to improve port efficiency, many developing countries see port 'efficiency' as a matter of only secondary importance; in the absence of social safety nets, 'keeping people working' is considered to be at least of equal importance.

This often leads to an additional labor problem facing many ports, which is the age structure of the workforce. The continuous surplus in the number of registered dock workers and the 'job for life' basis on which they are in practice employed can discourage employers from recruiting new, younger staff. That was the case in the UK where the average age of registered dock workers increased from 44.2 years in 1980 to 47.1 years in $1988 .^{25}$ In the same year, the percentage of

\footnotetext{
23 As reported in New York Times (2017), a 'privileged' docker pulled down more than $\$ 400,000$ in a single year because he was almost never off the clock, not even when he was at home sleeping.

24 In many western ports, salaries well over $\$ 100,000$ per year are not uncommon.

25 As a measure of comparison, before the Australian Waterfront Reforms came into force, the average age of the workforce was over 50 years.
} 
those over 50 years of age amounted to $42.5 \%$ and that of those under 35 years to $6.5 \%$. Subsequently, after the abolition of the Dock Labor Scheme, the former 'scheme ports' sought not only to reduce the size of their cargo-handling manpower, but also to reduce its average age and to improve its age profile.

Regularization of port employment has also created large numbers of different job categories. Often, strict demarcation lines between different jobs and different activities exist, a fact that severely limits, and in many cases totally prohibits, the transferability of workers from one activity (job category) to another. The above labor rigidities often lead to large gang sizes, excessive overmanning, little labor mobility, and high port user costs. In many ports around the world, the inflexible and monopolistic supply of port labor has effectively discouraged intended private sector activities around the port and has, thus, deprived the latter from one of its main functions, that of being a "growth pole" for the region and the country.

\section{Measures (and degrees) of port reform ${ }^{26}$}

Considerable confusion and uncertainty surrounds the term port reform and its various manifestations, which may range from a simple reorganization of the internal management procedures of a port authority, to the outright sale of port land, i.e., privatization. For the purposes of this paper, port reform should be taken to mean a process of change and transformation, through the introduction of private sector characteristics in public port administrations, aimed to improve port efficiency and performance.

Given the admittedly complex economic and legal nature of the issue, this confusion is in most cases unintentional. Indeed, differences between the concepts of, say, commercialization and corporatization, or between a lease license and a concession contract, are often not easily discernible, even among experts. But the complexity of the issue of port reform has often been used strategically in order to resist change, notably by declared statists or public sector employees. The most common method of doing this is through the use of the word privatization-a word that admittedly carries a lot of negative connotations-as synonymous to reform. ${ }^{27}$ In what follows, the various types of

\footnotetext{
$\overline{{ }^{26}}$ This section was only modesty updated since it was first written. A lot of things have changed since in port reforms, such as concessions' legislation; labor laws, emergence of Global Terminal Operators; dedicated (carrier) terminals; and much more. These have been addressed in separate publications, including those in my blog: www.haralambides-mel.blogspot.com.

27 I vividly remember Greece's socialist ex-prime minister, George A. Papandreou, at that time leader of the main opposition party PASOK, in the middle of the tear gases of the riot police, proclaiming that the government, by offering a concession of a terminal of the port of Piraeus to the Chinese company COSCO, was selling off the 'crown jewels.'
} 
port reform are discussed in order of increasing need for change and private sector involvement, compared to the traditional situation of a publicly owned and operated port which serves as a starting point.

\section{Improving port administration}

The improvement of port management and administration, within an existing organizational structure and without changes in law or national policy, can be seen as a first step towards port reform. As can be seen from Table 3, the need for such improvements is widely felt in most ports. Surprisingly, however, carried away by the well-publicized merits of more radical port reforms, ports and governments often tend to neglect the sometimes substantial benefits that can be reaped by improving the port's organizational structure; information systems; managerial techniques; financial management; setting clear objectives; training; empowerment of staff; team-work; and the development of a corporate culture: attributes that should be considered as prerequisites to more radical reforms anyway. Above all, management restructuring requires strong and competent leadership which, more often than not, unfortunately, cannot be found among the retired civil servants, or navy admirals, who customarily frequent the chair of a port authority's president in many countries.

Managerial restructuring is of a twofold importance. First, without going into institutional restructuring which may lead to painful social impacts, managerial measures can bring some rather positive results to port performance. In the port of Casablanca, for example, work was streamlined by setting clear objectives for each department and working team. Also, the introduction of a new management information system (MIS) could now allow managers more efficient control on port processes. The second big advantage of management restructuring is that these efforts can constitute a favorable springboard for further institutional steps. As the deputy general manager of the port of Odessa, Russia, said “... we have no experience in planning or pricing, only in obedience...” Much more recently, at another European port, its president (a retired coastguard admiral-something quite common in that country) used to say to his staff: "you are not here to think; you are here to do what I tell you...” It would thus be difficult, if not impossible, to upgrade a port's services through institutional measures, when basic management skills are not adequately developed or modernized.

\section{Liberalization (deregulation)}

Under 'liberalization,' the private sector is allowed to provide port services, sometimes in competition with the public sector. Liberalization entails the removal of statutory restrictions limiting entrance of the private sector to the port services market, and of discriminatory rules discouraging competition. 
Table 3: Types of port reform programs

\begin{tabular}{lcccc}
\hline & $\begin{array}{c}\text { Global } \\
(\%)\end{array}$ & $\begin{array}{c}\text { Europe } \\
(\%)\end{array}$ & $\begin{array}{c}\text { South and Central } \\
\text { America (\%) }\end{array}$ & $\begin{array}{c}\text { South East } \\
\text { Asia (\%) }\end{array}$ \\
\hline Improving port administration & 43 & 37 & 25 & 85 \\
Liberalization/deregulation & 28 & 11 & 37 & 40 \\
Commercialization & 45 & 37 & 37 & 25 \\
Corporatization & 17 & 21 & 37 & 30 \\
Privatization & 16 & 11 & 37 & 30 \\
Other & 19 & 21 & - & \\
\hline
\end{tabular}

Percentages may not tally due to multiple answers

Source IL0 (1995b)

Eventually, these restrictions are replaced by regulations that encourage or even require competition. For some countries, the advantage of liberalization is that the introduction of some form of competition in port services leads to efficiency improvements, while the overall regulatory control over the (strategically important) port remains completely in the hands of the port authority or the relevant government department.

Obviously, decentralization is a sine qua non for greater port management freedom and autonomy. However, decentralization alone cannot solve the problem of lacking management incentives or competencies; having the power does not necessarily mean using it as well, and in many cases, doing nothing is considered much safer than doing something. What William Baumol (1959) called the "security of the management team" has a big role to play here: focusing on performance and the need for change may require some rather hard-nosed decisions, e.g., forced redundancies, that could threaten the "survival" of the management team. The latter would thus opt for passivity rather than action. As R.A. Gordon (1945) has so succinctly put it "...the management of corporations do not receive the fruits which may result from taking successful action, while their position in the organization may be jeopardized in the event of a failure..." For instance, reformers in China, and in many other countries as well, were caught in the decentralization/re-centralization cycle: Once decentralized, power and authority were quickly abused, disorder occurred, control was called for, power and authority were taken back by the center, and the situation was back to its original state. Then another cycle started with redecentralization and the old scenario repeated itself. This is a common situation in many countries, where not only the necessary legislation for decentralization is inadequate, but the mechanisms and institutions (banking; judicial; business ethics; market culture; etc.) of a market economy are not in place. Old control has been given up, while new (regulatory) control has not been created. ${ }^{28}$

\footnotetext{
${ }^{28}$ In many cases, the transition of former socialist countries to 'market economies' has created incredibly rich oligarchs; corruption; poverty; violence; or even economic default. All this, because of the lack of 'institutions' which are the sine qua non for democratic governance. Years
} 
A disadvantage of deregulation is the potential danger of cream skimming. The private sector will only be interested to provide those port services that are potentially profitable, e.g., container terminal operations. In a public 'service' port, however, the sometimes unprofitable-albeit required port services, such as security - can be cross-subsidized by the profitable ones (cargo handling). Thus, as a result of liberalization, the port authority may be losing revenues from profitable port activities, having at the same time few possibilities for crosssubsidization. This issue should be seriously considered when leasing out port facilities to private operators: If the port authority is to continue providing commercially unprofitable services, and in the absence of central/regional government support, lease payments of private operators should be determined at a level that would allow the efficient provision of the various port services entrusted to the port authority. ${ }^{29}$ Such an arrangement is also in the interest of the private operators themselves, given that their efficiency improvements in cargo handling can be easily nullified by inefficient dredging, mooring, pilotage, towage, engineering, security, fire protection, and similar operations entrusted to the public port authority.

Furthermore, ports in many countries have been run for a long time as administrative entities with both infrastructure and superstructure belonging to, and often operated by, the port authority itself. In such cases, deregulation does not automatically bring in new competition because the latter is restricted by cumbersome bureaucracy, obsolete regulations, and lack of local management knowhow. This is particularly the case when tenders are only advertised locally and/or in the national language which, naturally, cannot entice foreign competition. It may well be then that after deregulation measures have been put in place, and efforts made to introduce competition, no new entrant is found to complement or compete with the old monopoly and force it to change. It could thus be easily realized that the old organization is too strong to be changed by (unassisted) market forces alone, and some more pro-active reforms may be required together with deregulation.

Footnote 28 continued

back, I remember Singapore's prime minister, Lee Kuan Yew, telling me that "it takes 200 years to become a country."

29 At Brindisi, the port dues we were charging to Ro-Ro ferry operators were roughly 1 Euro per passenger, while security only was costing us 3 euro/passenger. What was even more interesting was that some ferry operators and their local agents would refuse to pay even this 1 euro, claiming that the port is a public facility, thus to be used by anyone without an obligation to pay! This was indeed a 'world first,' lasting for years, with debts to the port authority accumulating year after year. Finally, even the thought of increasing port dues, in order to cover costs, would be immediately met by the threat of ferry operators of leaving the port for the neighboring port of Bari, which would be more than happy to welcome them. 


\section{Commercialization}

Commercialization implies the introduction of a commercial, business-like, environment, in which the port management is accountable for its decisions and performance. In the previous stages above, ports still retain their status as quasigovernment departments. In the commercialization stage, the status of a stateowned enterprise is justified, as the previous "government department" now changes into a public company.

The main objective of commercialization is to increase management autonomy and accountability (World Bank 1994). If port managers in public port organizations are not held responsible for port performance, they will not always take all the necessary steps for securing cost reductions or improvements in productivity. Furthermore, as the management of commercialized ports is still public, it often hesitates to consider, in time, possible reductions in employment. Port labor contracts are usually not governed by regular labor law, but they have a quasi-civil service status. Solutions to the above situations could be found in an increased accountability for port managers and workers, or in the contracting out of certain port functions to the private sector. Several approaches are in use to achieve this:

- Performance agreements These clarify performance expectations and the functions, responsibilities, and rewards of all parties concerned. Performance agreements are usually part of annual staff assessments, thus reviewed regularly and, if necessary, adjusted from one year to the other.

- Management contracts Under this arrangement, the management of an operation (e.g., port security) is transferred to a private entity. The latter offers managerial expertise and knowhow, but the port authority retains ownership (of security infrastructure such as fences, cameras) and overall control.

- Service contract/contracting out This method consists mainly of the contractually specified transfer of responsibilities to a private entity for the provision of a certain service (e.g., ICT and Port Community Systems). A service contract is usually described in more detail than a concession (see below).

- Lease: Under this agreement, assets are leased for a fixed period to private lessees. The ownership remains with the (public) lessor. Among the many different types of leases that exist, the following two types are frequently used in the port industry:

- A flat rate lease where a fixed amount is agreed and eventually adjusted for inflation. The amount is based on a fair return on the value of the property, often centrally and statutorily determined. 
- A mini-max lease, where the lease amount is variable and it is determined in relation to the actual throughput. The lease increases by steps within a minimum-maximum scale. In contrast with the flat rate lease method, there is no maximum level of compensation included in this option. The upper limit is determined by, for example, terminal capacity.

- Concession A concession is an agreement similar to a lease in that the use of facilities is transferred for a predetermined period by the owner to a potential user, but with a substantial amount of control retained by the owner (the public port authority) on the concessionaire's use of the rights. Upon expiry, the facilities have to be returned to the owner in good condition and free of charge.

Port commercialization works, simply because it allows the port to fix its overarching objective on market needs and customer satisfaction. However, the most difficult part is not to introduce change, but to maintain an unswerving pursuit of targets and a continuous dynamism. In Morocco, ODEP (Office d'Exploitation des Ports) adopted two methods in order to sustain the positive results that followed commercialization. One was to promote and use private management philosophy and methods, and the other to create fictitious competition where real competition could not exist. Private management philosophy meant the introduction of a series of modern port management tools, such as cost control; financial audit; rigorous personnel policy; and more discipline. Most importantly, a management contract was concluded between ODEP and the government, enabling the former to have clear objectives, responsibility, and a high level of freedom and autonomy in its management. The creation of fictitious competition meant regular benchmarking with different ports on their productivity; relationship with clients; and management practices. Furthermore, comparisons of "competition" were also made within the same port, among various activity centers (e.g., stevedores), which had been created as autonomous entities. Evaluation was undertaken by the general manager's office, with standards based on market requirements. Reward and sanction measures were also exercised.

\section{Corporatization}

Corporatization requires the transformation of public sector organizations (SOEs) into publicly listed private companies, the shares of which are held in majority by the public sector (central and/or municipal government). Although enterprises in the commercialization stage are introducing more private sector characteristics in their operations, they still lack the legal corporate 
independence often needed to ensure efficient operations. Corporatization affords the enterprise a status of independence and subjects it to the same legal requirements as those of a private firm. A whole new company is thus established, enjoying administrative and financial flexibility and autonomy, enabling it to close agreements, and make decisions on pricing; investments; and human resources, without continuous reference to the government. All land and moveable and fixed assets are transferred to the new company as paid-up capital.

A significant advantage of corporatization is to be found in its commercial accounting procedures, which make financial cost control more transparent, thus facilitating the identification of sources of inefficiency. As the government does not exercise direct control over port management, corporatization is in general a more attractive alternative to foreign investors than the other stages of port reform discussed above.

\section{Privatization}

Privatization is the most radical and possibly most complex exercise in port structural adjustment programs. It could be defined as the conditional, and often transitory, transfer of port ownership from the public to the private sector. However, although this definition serves a methodological purpose, pure privatization such as this is rarely found in practice. In many cases, the increasing private sector participation in the management; operations; and development of ports (described above as commercialization/corporatization) would also be often defined as "privatization.” Privatization can take various forms:

- Public offering In those cases where (part of) the shares of the port company are listed on the stock exchange, and can thus be freely traded, the government may decide on a public offering. It may also decide to retain a major part of the stock (corporatization) in order to exercise control over future port activities.

- Management/employee buy-out In this situation, the government decides to divest its shares to the employees, so that the latter assume ownership of the port. A buy-out would be more appropriate whenever the employees are highly motivated and keen on buying the company. Demand prospects have to be stable and the size of the port should be rather limited.

- Private placement Through a process of competitive tendering, various potential private investors can submit a quotation. By negotiation, the government can then decide which offer is the most attractive. It is possible that offers are made by a consortium of companies, banks, or even a group of employees. 
- BOO/BOT In this case, a private company Builds, (Owns) and Operates an asset for a certain period. Under a BOT arrangement, at the end of the period the asset is Transferred back to the government. If privatization takes place in this way, the private sector is given an exclusive concession to operate an infrastructural project, such as a bridge or a port terminal, and it assumes the risk of completing it. BOO/BOT is a form of non-debt financing of public sector activities, in which the private sector finances the construction and the costs are recovered through user fees. Depending on the project, incentives may include guaranteed purchase of output, tariff support in the early years, concessionary rates of income tax, free repatriation of dividends and capital, and exemption from customs duties, turnover tax, and excise duties.

- Sale of assets This alternative can be considered when private investors are not interested in acquiring the whole of the company, or when better results can be expected through a partial rather than an outright sale.

- Joint venture A joint venture represents an enterprise in which two or more private companies, or an SOE and private investor(s), jointly own the equity of the port company.

Most countries actually experiencing port privatization have adopted public-private joint venture options. Port joint ventures are often attractive to both government and the private sector. The former can reduce administrative and financial burdens, improve efficiency, and promote competition. The private sector views this arrangement favorably whenever the magnitude of the required investments, and associated commercial risks, is beyond its capabilities, or when complete ownership of assets and operational control are not allowed.

In the port of Bremen, most of cargo-handling operations are carried out by a joint venture company (BLG) of the city of Bremen (51\%) and the private sector. The same formula can be found in many other developing countries, such as the port of Cochin in India (container terminals with foreign private partner), the port of Shanghai in China (50\% private ownership of the container terminal, 50-year joint venture), the port of Saigon in Vietnam, the port of Szczecin in Poland, the Free Port of Malta.

However, one of the most notable examples is Port Klang in Malaysia. The operational services of the container terminal were privatized in 1986. Tenders were invited from interested local parties, based on well-specified terms of reference, and the container operations were awarded to Klang Container Terminal (KCT), the first port operating company in Malaysia, set up as a joint venture between the Klang Port Authority (49\%) and Konnas Terminal Klang $(51 \%)$. The latter was a joint venture between the state-owned container 
haulage firm Kontena Nasional (80\%) and P\&O Australia Ltd. (20\%). The new company (KCT) bought the non-fixed assets such as cranes and equipment, while fixed assets, such as quays and buildings, were leased for a period of 21 years. A condition of KCT's privatization was that the company would eventually be listed on the stock exchange. As a result, KPA's share was reduced to $20 \%$, that of KTK's to $40 \%$, and the general public held the remaining $40 \%$.

\section{Interim port reform authority}

The structural adjustment of ports is a complex process, with many interests involved and with a significant impact on port management, workers, and employees. The fact that many ports are natural monopolies makes such adjustment even more complex. The existence of an interim authority, which controls and directs the structural adjustment process, can facilitate its smooth and effective implementation. Several recent port privatization efforts have made use of such an arrangement. The "Steering Committee" in Thailand and the "Waterfront Industry Reform Authority” (WIRA) in Australia are only two examples.

An interim port authority usually comprises representatives of the relevant government departments, often supported by a team of experts. The latter is usually multi-disciplinary in nature and it includes representatives of the private sector. An interim authority has several tasks, the most important of which is the selection of an appropriate strategy for privatization. Thus, the evaluation of the suitability and/or desirability of the different privatization alternatives would be one of this authority's main challenges. Another important task of the authority is related to the establishment and control of a tendering procedures (discussed below). Here, the interim authority can further assist in the negotiation process and the evaluation of the various bids.

\section{Tendering procedures}

Usually, several private companies will express their interest in bidding for the provision of port services. As there are many interests at stake, the selection of the most economically and technically attractive bid is an exercise that requires powerful skills, transparency, and objectiveness. Among many other cases, experiences from the privatization process of the Songkhla and Phuket ports in Thailand showed that:

- Potential bidders should be provided with clear objectives of the contemplated tender, together with ample information on the basis of which they can determine their commercial interest. Requirements that bidders have to meet should be stated in as much detail as possible in order to ensure that only those qualifying are encouraged to bid; 
- A standard format should be adopted regarding the information that should be submitted by the bidder (company profile and structure, business plan, financial performance, capabilities);

- Bids should include a detailed business plan on the envisaged operations, encompassing the inevitable market research and a comprehensive appraisal of business prospects. Surprisingly enough, given the amounts of investment required, this is not often the case. Investors may thus belatedly realize that if they are to make an acceptable return on their capital, they must either raise their service charges, and/or demand additional privileges (e.g., lower taxes, throughput targets, provision of supplementary infrastructure, such as connecting roads and rail). These, however, are generally unacceptable, as well as illegal, ${ }^{30}$ solutions which contradict the main argument favoring reform, i.e., reduced transport costs through higher efficiency.

To ensure an objective appraisal of all competing bids, the evaluation should rely on several clearly defined, significant criteria. However, a completely objective judgement is extremely difficult, as the assignment of weights to the various evaluation criteria is always subjective (e.g., weights assigned to the 'technical' and 'economic' offers). Since the case of one bidder clearly dominating all others on all counts is rather rare, an a priori consensus, and possibly quantification, on the weights to be attributed to the various evaluation criteria is a sine qua non. Agreement on this can substantially ease the onerous task of the evaluation team, it adds transparency and shortens the decision time.

Related to the above is the issue of the correct valuation of the to-beprivatized port asset or service. Clearly, such a valuation ought to be based on the discounted cash flow of the operation and this, in its turn, should reflect the general economic prospects of the country. If privatization is contemplated primarily on ideological grounds, or due to 'cash' contingencies, and in the absence of a reasonably defendable national master plan, governments may be tempted to undervalue port assets in an effort to make them more commercially attractive to the private sector. The United Kingdom has seen the publication of a House of Commons Select Committee Report criticizing the way the first five trust ports were undervalued and undersold by the UK government. A more recent example is that of Piraeus, Greece, where the port was 'sold' to COSCO Pacific at a price which, in Rotterdam (or in any other major, busy port), would buy them just a berth!

In the case of Medway, the port was sold through a MEBO. The 250 employees obtained a $51 \%$ share in the equity of the new port company, with

\footnotetext{
${ }^{30}$ In the sense that such "adjustments" have an impact on the concession contract and, were they to be known at the time of bidding, the outcome (winner) might have been different.
} 
the remaining $49 \%$ shared among five persons. The shares could be bought at a price of $£ 1$ per piece, during the privatization, but two years later the port was sold to a new owner for almost eight times the amount the government had originally received, making the share worth over $£ 37$ each (Baird 1994).

A similar rise in share prices occurred in the case of Forth Ports. There, the privatized ports were in fact "estuarial monopolies." Next to owning the port's assets, port companies also assumed regulatory functions, including inland navigation, previously the responsibility of the port authority. It has been alleged that port companies had actually used these powers to effectively stop a competitor from building new harbor facilities in the area of the former trust port.

\section{Concluding considerations}

It has already been noted that, nowadays, the increasing Internationalization of all forms of economic activity, mass media, modern telecommunications, and foreign experts, intrigues countries to attempt international efficiency comparisons with other nations, many of which found at a completely different stage of economic and social development, and with institutional frameworks that were set up centuries ago. If superficially attempted, such comparisons can be extremely dangerous and misleading, particularly when successful economic reforms in other countries are taken prima facie, without a thorough understanding of all their implications, and without adequate comprehension of the simple fact that, if proper institutions are not in place, the future of economic reform, and to that effect the country's economic development by and large, cannot be taken for granted.

To give a simple example, the listing of a privatized port's shares in the country's stock exchange would be next to pointless, if the stock exchange is not functioning properly, the volume of transactions and its liquidity are low, the dissemination of market information is inadequate, and if capital markets, in general, are inefficient. In situations such as these, the real value of the port will be far from being reflected in the nominal value of its shares and, thus, domestic and foreign investors' interest could not be expected to be significant.

To enhance the possibilities of survival in a competitive environment, the government can improve the institutional environment of the port, thereby enhancing its ability to respond adequately and promptly to the changing market conditions. Several well-documented divestiture experiences show that certain prerequisites regarding the port's economic environment have to be met, if the full benefits from divestiture are to be realized. A hospitable and efficient business environment has, thus, to exist; distortions that hinder domestic and 
foreign competition eliminated; and an efficient capital market with considerable absorptive capacity developed.

In addition, the retrenchment of the State from economic activity and the encouragement of greater private sector participation should be based on a careful, long-term, social cost-benefit analysis, undertaken by the government. The results of this analysis should form the government's basis for designing and implementing programs of economic reform. Government strategy, once decided, should be firm, with clear and transparent objectives, and it should be widely explained through a process of extensive consultation, particularly with those parties that are adversely affected by the proposed reforms. The importance of consultation in structural adjustment programs could not be over-emphasized, not only in securing labor's co-operation, but also in convincing the latter that the attempted reforms aim at enhancing the country's general economic welfare, which should be every government's utmost objective. This strong message has to be successfully and timely conveyed to trade unions and employees.

The problem here is that the wider, long-term, benefits of economic transformation are not immediately and directly visible by all those, whose short-term well-being is adversely affected by the reforms, and it is only with the co-operation and consent of the latter that the reform process can be concluded in a frictionless and socially acceptable way. Employees have to be firmly convinced that government retrenchment and economic austerity measures serve the nobler objectives of raising incomes and standards of living, as well as eliminating poverty, and as such affected workers should also receive their fair share.

The co-operation of trade unions should also be secured by convincingly arguing that, instead of their fruitless, short-run, pursuit of job-preservation in a rapidly changing technological environment, it would be to their members' best interest were they to embrace more positive attitudes aiming at future jobcreation. However, such arguments are bound to be more difficult to handle, particularly whenever it becomes evident that the new jobs are intended to be in the private sector, through enterprise-level labor agreements which tend to reduce union density and, thus, unions' influence in formulating labor policies.

Upon adopting a consistent, nation-wide, strategy on economic reform, governments should not fail to internalize all the social costs incurred as a result of their divestiture programs. The economic and social costs of redundancies should, thus, figure rather prominently among them. Assuming that, through privatization, the government's objective is to raise the general economic welfare in the long-run, it would make sense to argue that workers who are made redundant due to the requirements of economic reform should be adequately compensated by those who are -or will be- benefiting from it. However, difficult to achieve, in a 'win-win' situation, redundancy 
compensation should somehow be related to the discounted cash flow of redundant workers' future earnings, had they remained employed.

For example, in the case of the Malaysian reforms, the government introduced a clause whereby employees opting to go to the privatized/ corporatized port were guaranteed employment for a minimum of 5 years at terms and conditions "no less favorable." In France, a compensation program was used, whereby redundant workers would either be retrained or receive financial compensation of about FFr 450,000 each. In New Zealand, a similar compensation system was put in place when the country's ports were corporatized in 1998-1989. Such a policy has also been used in the UK, following the abolition of the National Dock Labor Scheme.

However, the experience of Malaysia may be specific or even exceptional because the country had been enjoying high economic and trade growth which had helped in avoiding layoffs or expensive retraining. Other countries, without a favorable economic climate, can hardly impose such mandatory conditions, because the existence of such redundancy costs would undoubtedly reduce the financial attractiveness of the to-be-privatized ports, it could dilute private sector interest and it might, thus, prolong the timely completion of the reform process.

The government has again a strong role to play in these deliberations: The various redundancy costs should not be contrasted only with the short-term financial prospects of the privatized port-which of course is the prime concern of the private investor-but with the long-term economic benefits of divestiture for the economy as a whole. If this is the prevailing principle, the government should bear itself the costs of redundancies and it should finance them centrally. This approach would then constitute a form of income re-distribution towards those who had to lose their jobs, so that others could maintain theirs presently and in the future. ${ }^{31}$

Another method, suitable for countries that are particularly concerned with issues of income distribution and accumulation of wealth, is the financing of redundancy costs by those who directly benefit from the economic reform. Employers of privatized companies are here called upon to assume a significant part of the redundancy costs themselves, and these costs should be a clear and quantifiable element in their business plans and investment appraisal exercises regarding the evaluation of the financial attractiveness of the to-be-privatized port facility. Given the long-term macroeconomic benefits of privatization, the government can-and normally should—share a part of these costs. Finding an

\footnotetext{
${ }^{31}$ This idea is not much different than the trade adjustment assistance programs, such as those envisaged, for example, in the Trans Pacific Partnership Agreement (TPP). In short, if a worker is displaced because his employer moved abroad, or went out of business due to cheaper imports, the worker is compensated, being also eligible for participation in retraining, funded by the assistance program itself.
} 
optimum allocation of redundancy costs between the private and the public sector should, thus, be one of the main issues in the design of port reform programs.

The above method makes a lot of economic sense, particularly in the port privatization attempts of less developed countries. It can be very defensibly argued that although the economic and social costs of port reform are borne by the country itself, the benefits from the increased port productivity, as a result of privatization, can very well accrue to the foreign shipping operators servicing the country's external trade. In this way, and in the absence of adequate competition in international shipping, higher port productivity is not necessarily reflected in lower transport costs, but perhaps in increased profits for the foreign transport operators. If that were to be the case, it would be reasonable to argue that the latter operators should bear themselves a part of the costs involved in increasing port productivity through, say, temporarily higher terminal handling charges and/or general port dues.

Again, in the absence of adequate competition in international shipping, levying shipping operators in order to recover reform costs may result in higher transport costs that could be easily passed-on to the final consumer. This would be particularly true if domestic commodity and product markets are either not developed, monopolistic or, in general, uncompetitive. However, given that redundancy costs are once-off or time-limited expenditures, the redistributional effects of such a situation would also be limited, and thus innocuous, as long as additional levies are not becoming a permanent element in the port's tariff structure.

Finally, the user pays principle should also be very welcome to foreign shipoperators, given their interest in the existence of efficient ports in their trading areas. This interest can be immediately understood: the benefits accruing to shipoperators from their investments in large ships and integrated transport systems can be easily withered by inefficient port operations at their ports of call.

Another important consideration regarding the effectiveness of increased port productivity, and the distribution of benefits from it, concerns the port's role within the overall supply chain. The efficiency of a port and the desirability of government divestiture and other port reform plans cannot be judged in isolation, but only within the wider economic framework the port operates. More and more ports in a large number of countries are losing their traditional function as merely interface points between land and sea and are assuming the much wider function of a crucial link in the production-transport-distribution chain. In this way, inefficiencies in the other parts of the chain can easily nullify all benefits derived from improved port efficiency.

For example, many otherwise efficient ports have been known to be faced with extremely bureaucratic and time-consuming customs regulations, resulting in unacceptably high container dwell times. In others, where handling rates of 
35 TEUs per crane-hour are boasted, it may take three hours from the gate to the motorway $(1 \mathrm{~km})$ due to excessive road congestion and to the fact that trucks have to transverse the city center. In a number of ferry ports, passengers and drivers have been known to be queuing for as much as $12 \mathrm{~h}$, under extreme weather conditions, in the middle of the city, without access to even elementary sanitary facilities, only because an advance-booking system is not considered by the shipping agents-operating in a cartel-as a good idea.

Bottlenecks and inefficiencies such as these in the port's operating environment can easily choke-off and annihilate any potential benefits from introducing commercial principles and practices in cargo-handling and/or other direct port services. If these issues are not seriously taken into consideration, port unions would be quite justified in arguing that, in cases like the above, their members would have to bear the consequences of divestiture, while the benefits are used to cross-subsidize other inefficient economic activities (such as the provision of inadequate road and rail capacity) where no reform is being planned in the near future.

The above notes are by no means meant to be taken as making the case against the introduction of commercial principles in port operations. The only point that is made here is that the successful implementation of port reform plans must fit within a general strategy of economic reform, where all its implications and consequences are thoroughly debated through honest and sincere social dialogue. Piece-meal, ad hoc, or unsubstantiated attempts to privatization are not likely to gain the support of unions and of the general public.

The economic reforms in Malaysia can again serve as a very good example of a correct way to privatization. In 1985, the beginning of the reforms, the government's Economic Planning Unit issued 'Guidelines on Privatization' for the purpose of [...] elaborating and clarifying the government's policy on privatization to both the public and the private sectors... and also to enlighten the employee and the general public on this subject...

The 'guidelines' were subsequently thoroughly debated at all levels, with the active participation of the country's prime minister, and most people were convinced that privatization and economic efficiency are the only road to the '2020 vision,' meaning the transformation of Malaysia into a fully developed economy by the year 2020. However, in order to put things in their proper perspective, it should be mentioned that due to the country's fast economic growth, privatization did not cost jobs and those employees that had decided to leave under an early retirement scheme were more than adequately compensated.

An important final point that could be made regarding the distribution of benefits from port divestiture programs concerns the very distinct possibility of creating private monopolies in the place of the former public ones. The effects of government divestiture, without adequate competition, are rather doubtful, and 
private monopolies-apart from reducing general economic welfare-may be socially undesirable too. Their existence does not necessarily reduce bureaucracy, as new regulatory bodies will have to be created to supervise their operations, so that they do not enjoy monopolistic profits to the detriment of the final consumer. Successful port privatization thus requires a regulatory framework that singles out potentially competitive activities, establishes the tariff regime, clarifies service goals, develops cost-minimization targets, and creates or strengthens an independent authority to supervise the process. Such a regulatory framework ensures that divestiture leads to increased efficiency without harming consumer interests (Kikeri et al, 1992, p. 6).

\section{References}

Acciaro, M. 2013. A critical review of port pricing literature: What role for academic research? The Asian Journal of Shipping and Logistics 29 (2): 207-228.

Adam, C., W. Cavendish, and P.S. Mistry. 1992. Adjusting privatization: Case studies from developing countries. London: James Curry Ltd.

Baird, A. 1994. Port Privatisation in the UK, A flawed process. In: Proceedings of the World Port Privatisation Conference 1994, London, United Kingdom.

Barros, C.P., H.E. Haralambides, M. Hussain, and N. Peypoch. 2011. Seaport efficiency and productivity growth. In International handbook of maritime economics, ed. K. Cullinane, 363-382. Cheltenham: Edward Elgar.

Baumol, W.J. 1959. Business behaviour, value and growth. London: Macmillan.

Baumol, W.J. 1977. On the proper cost tests for natural monopoly in a multiproduct industry. American Economic Review 67: 809-822.

Beplat, K. 1989. Mega trends in containerization: Directions and projections. Hamburg: Reinecke \& Ass.

Bureau of Transport and Communications Economics. 1988. Economic Significance of the Waterfront. Information Paper 29, Australian Government Publishing Service, Canberra.

Campbell, D. 1994. Foreign investment, labour immobility and the quality of employment. International Labour Review 133 (2): 185-188.

Couper, A.D. 1986. New cargo-handling techniques: Implications for port employment and skills. International Labour Office, Geneva.

Dicken, P. 1992. Global shift: The internationalization of economic activity. Paul Chapman Publishing Ltd., London, Chapter 2, 4, 6, 13.

ESPO. 2010. European Port Governance: Report of an Inquiry into the Current Governance of European Seaports. European Sea Ports Organisation (ESPO), 2011.

European Commission. 2013a. Proposal for a regulation of the European Parliament and of the Council establishing a framework on market access to port services and financial transparency of ports. COM (2013) 0296 final.

Gordon, R.A. 1945. Business leadership in the large corporation. Brookings Institution, Washington D.C. (published in cooperation with University of California Press).

Goss, R.O. 1993. Port privatisation: The public interest. In: Proceedings of the 9th Port Logistics Conference, Alexandria, Egypt.

Haralambides, H.E. 2002. Competition, excess capacity and the pricing of port infrastructure. International Journal of Maritime Economics 4: 323-347. 
Haralambides, H.E. 2012. Ports: Engines for growth and employment. European Ports Policy Review: Unlocking the Growth Potential. European Commission, Brussels, 25-26 September 2012 .

Haralambides, H.E., A. Verbeke, E. Musso, and M. Benacchio. 2005. Port financing and pricing in the EU: Theory, politics and reality. In World shipping and port development, ed. T.-W. Lee, and K.P.B. Cullinane, 199-216. Basingstoke: Palgrave-Macmillan.

Haralambides, H.E., and G. Gujar. 2011. The Indian dry ports sector: Pricing policies and opportunities for public-private partnerships. Research in Transportation Economics 33 (2011): 51-58. doi:10.1016/j.retrec.2011.08.006.

Haralambides, H.E., and M. Acciaro. 2015. The new European port policy proposals: Too much ado about nothing? Maritime Economics and Logistics 17 (2): 127-141.

Harding, A.S. 1990. Restrictive labour practices in seaports. The World Bank, Washington (WPS 514).

ILO-International Labour Organisation. 1995a. Social and labour problems caused by structural adjustment in the port industry of selected countries in the Asia-Pacific region, Geneva.

ILO-International Labour Organisation. 1995b. Social and labour effects of structural adjustment programmes in the world port industry. Geneva.

Kikeri, S., J. Nellis, and M. Shirley. 1992. Privatisation: The lessons of experience. World Bank Publication, Washington D.C.

Kotwal, M. 1992. Indian country report presented at the Asia/Pacific Rim Dockers' Seminar, Yokohama, International Transport Workers Federation, 5-7 October 1992.

Milanovic, B. 2012. Global income inequality by the numbers: In history and now-An overview. World Bank Policy Research, Working Paper 6259 (Washington). http://elibrary.worldbank. org/doi/pdf/10.1596/1813-9450-6259.

Mosca, M. 2008. On the origins of the concept of natural monopoly. The European Journal of the History of Economic Thought 45 (2): 317-353.

Musgrave, R. 1969. Provision of social goods. In Public economics, ed. J. Margolis, and H. Guitton, 1969. New York: Martin's Press.

New York Times. 2017 The Mob’s Last Candy Jar, January 8, 2017, p. MB1.

Notteboom, T., P. Verhoeven, and M. Fontanet. 2012. Current practices in European ports on the awarding of seaport terminals to private operators: Towards an industry good practice guide. Maritime Policy \& Management 39 (1): 107-123.

OECD-DAC. 1993 Development co-operation: Aid in transition. Report by A.R. Love, Development Assistance Committee (DAC), pp. 39-42.

Oxford Economics. 2011. The New Digital Economy: How it will transform business. A research paper produced in collaboration with AT\&T, Cisco, Citi, PwC \& SAP.

Port Development International “Thailand, the privatisation process”, November 1988, pp. 16-21.

Port Development International "Privates on Parade”. December/January 1993, pp. 33-53.

Ports and Harbours Bureau of Japan, Ministry of Transport. 1993. Ports and harbours in Japan 1993. Japan: Ministry of Transport.

Rimmer, P. 1984. Japanese seaports: Economic development and state intervention. In Seaport systems and spatial change, ed. B. Hoyle, and D. Hilling, 99-134. Chichester: Wiley.

Rosenstein-Rodan, P.N. 1943. Problems of industrialisation of Eastern and South-Eastern Europe. The Economic Journal 53 (210/211): 202-211.

Shirley, M. and J. Nellis. 1991. Public enterprise reform: The lessons of experience. Economic Development Institute of the World Bank, EDI Development Studies, Washington D.C.

Singh, A. 1994. Global economic changes, skills and international competitiveness. International Labour Review 133 (2): 167-183.

Shoup, C.S. 1969. Public finance. Chicago: Aldine.

Slack, B. and J. Starr (eds.). 1994. Containerization and the load centre concept. Maritime Policy and Management (special issue) 21:3: 185. 
The Economist. 2016. “Rigging the bids”. 19 November 2016.

Thomas, B. 1994. The privatization of United Kingdom seaports. Maritime Policy Management 21 (3): 181-195.

World Bank. 1994. World Development Report 1994: "Infrastructure for Development", 1994. New York: Oxford University Press. 